\title{
CEsifo WORKING

\section{Why the Current Tax Rate Tells You Little: Competing for Mobile and Immobile Firms}

Dominika Langenmayr, Martin Simmler 


\section{Impressum:}

CESifo Working Papers

ISSN 2364-1428 (electronic version)

Publisher and distributor: Munich Society for the Promotion of Economic Research - CESifo $\mathrm{GmbH}$

The international platform of Ludwigs-Maximilians University's Center for Economic Studies and the ifo Institute

Poschingerstr. 5, 81679 Munich, Germany

Telephone +49 (o)89 2180-2740, Telefax +49 (o)89 2180-17845, email office@cesifo.de

Editors: Clemens Fuest, Oliver Falck, Jasmin Gröschl

www.cesifo-group.org/wp

An electronic version of the paper may be downloaded

- from the SSRN website: $\quad$ www.SSRN.com

- from the RePEc website: $\quad$ www.RePEc.org

- from the CESifo website: www.CESifo-group.org/wp 


\title{
Why the Current Tax Rate Tells You Little: Competing for Mobile and Immobile Firms
}

\begin{abstract}
Firms should use all available information to anticipate future tax rates. Firm mobility, as a key determinant of corporate tax rates, is one such source of information. We first show theoretically that a government sets a higher tax rates on firm profits if average firm mobility in its jurisdiction is low, and that the potential entry of immobile firms in the future deters firms from entering a jurisdiction today. We then test and confirm these predictions in a well-identified setting, using the rapid growth of wind power plants (a very immobile industry) and the large variation in local business taxes across Germany for identification.
\end{abstract}

JEL-Codes: H250, H710, F210.

Keywords: corporate taxation, firm mobility, commitment, tax competition.

\author{
Dominika Langenmayr \\ KU Eichstätt-Ingolstadt \\ Ingolstadt / Germany \\ dominika.langenmayr@ku.de
}

\author{
Martin Simmler \\ University of Oxford \\ Oxford / United Kingdom \\ martin.simmler@sbs.ox.ac.uk
}

December 2017

We thank Johannes Becker, Steve Bond, Andreas Hauer, Ben Lockwood, Rainer Niemann (discussant), Georg Schaur, Kurt Schmidheiny (discussant), Johannes Voget (discussant) and participants at conferences by the German Economic Association and the Royal Economic Society, the MaTax conference, the summer symposium of the Oxford Centre for Business Taxation, the Norwegian-German Seminar for Public Economics, the CESifo Venice Summer Institute, and at seminars at the Universities of Bochum, Dublin, Linz, Munich, Oslo and Oxford for very helpful comments. Work on this paper was started when Dominika Langenmayr was visiting Oxford University Centre for Business Taxation, she is grateful for their hospitality. We gratefully acknowledge financial support from the German Research Foundation (Langenmayr: LA 3565/1-1, Simmler: SI 2050/1-1). 


\section{Introduction}

Governments cannot tax highly mobile firms at high rates. If a government tries to do so, mobile firms will move to other jurisdictions. While economic theory has long argued along these lines, there is little direct empirical evidence for this fundamental relationship. ${ }^{1}$ In this paper, we contribute to filling this gap. We exploit the evolution of a new, immobile industry (wind turbines) in Germany and provide direct evidence for the effect of capital mobility on corporate tax rates. As we will argue below, wind turbines provide an ideal testing ground, as their relocation costs are prohibitively high, and exogenous, observable factors such as wind speed mostly determine their location decision. Thus, a first contribution of our paper is to show in a well-identified setting that corporate tax rates increase in response to declining capital mobility.

Given the theoretical importance of capital mobility as a determinant of tax rates, we ask in a second step if firms use likely changes in capital mobility to anticipate future tax rate changes. Anticipating future tax rates can have important consequences: Consider, for example, a firm that decided in 2000 to invest in either the US or Canada and is indifferent between the two locations regarding non-tax factors. In that year, both the United States and Canada had a corporate tax rate (including average state taxes) of around $40 \%$. Over the next ten years, Canada lowered its tax rate by more than ten percentage points, while the U.S. tax rate remained constant. If our hypothetical firm foresaw the changes, it would have preferred to invest in Canada. A second contribution of our paper is to show that firms indeed anticipate future tax rates in their location decisions.

In more detail, our paper starts by setting up a model in which local governments compete for mobile and immobile firms (i.e. firms with very low or very high relocation costs). We show that governments face commitment problems as a higher share of immobile firms poses an incentive to increase the tax rate. Accordingly, mobile firms prefer to enter in a jurisdiction with a low potential tax base of immobile firms (i.e. with a relatively large number of mobile firms and a low risk of immobile firms entering in the future), as these factors indicate that the tax rate will stay low in the future.

\footnotetext{
${ }^{1}$ As exogenous variation in capital mobility is rare, empirical tests have used various proxies, such as industry-specific location rents, measured e.g. by geographic profit variability (Carlsen et al., 2005), or indicators of globalization, measured e.g. by the relaxation of capital controls (Devereux et al., 2008) or trade openness (Slemrod, 2004).
} 
Our model assumes that all firms are taxed at the same rate. ${ }^{2}$ Thus, governments cannot target policies to specific firms, but must base their tax rate decisions on the overall mobility mix of the tax base. Likewise, firms' expectations about future tax rates depend on their expectations about the mix of the tax base, not their own mobility. This set-up differentiates our paper from earlier literature (discussed below), which studied the hold-up problem for the taxation of individual firms (e.g. in the context of tax holidays).

In our empirical tests, we use the evolution of wind power plants in Germany after 2000. Due to generous subsidies for green electricity financed by the federal government, the number of wind turbines increased from roughly 5,000 in the year 2000 to over 23,000 in 2012. Since the most important factor in the location decision of wind turbines is wind strength, our setting allows us to explore exogenous variation in the tax base share of immobile firms across German municipalities. Together with the relevance of municipality level local business taxes, which account for half of the tax burden on firms' profits in Germany, and the uniformity of the tax base across municipalities, this setting is well suited to our research questions.

Based on panel data from 1999 to 2011 and using OLS and IV estimations, we show that municipalities increase the tax rate on immobile and mobile firms' profits by on average $6 \%$, or roughly 1 percentage point, if the tax base share of immobile firms increases from 0 to $50 \%$. This is consistent with evidence from case studies: The municipality of Ellhöft, for example, had not changed its local business tax rate for nine years, but increased it by $25 \%$ after four wind turbines were built there in 2007 (and building permits had been issued for three additional turbines). ${ }^{3}$

To test whether firms anticipate such changes in tax rates, we study firms' location decisions by estimating a Poisson model of entry at the municipality level. Our results suggest that an increase in the potential tax base share of immobile firms deters (non-

\footnotetext{
${ }^{2}$ This assumption corresponds to common real-world policies, especially for small and mediumsized firms. Large multinational firms may be able to bargain for specific subsidies or tax holidays, or lower their effective tax burden via profit shifting. In the context of the small, local jurisdictions studied in this paper, however, all firms are usually subject to the same statutory rate.

${ }^{3}$ Ellhöft, a village of 113 inhabitants at the German-Danish border, receives several hundred thousand Euros in tax revenues from those wind turbines each year. Major German newspapers reported on the financial gains of wind turbines for small municipalities (see e.g. www.spiegel.de/wirtschaft/ soziales/energiewende-wie-windkraft-ein-113-seelen-dorf-reich-machte-a-1078759.html for Ellhöft or www.mz-web.de/merseburg/windpark-farnstaedt-dank-wind-soll-s-in-der-kasse-klingeln-3329750 for Farnstädt, a village of 1,648 inhabitants in Saxony-Anhalt).
} 
wind turbine) firms from entering in a particular jurisdiction today. On average around $12 \%$ fewer new firms enter a jurisdiction if the potential tax base share of immobile firms increases from 0 to $50 \%$. As wind turbines require almost no labor input while running, this effect does not arise because of higher local wages. In addition, we show that for firm entry the potential tax base share of immobile firms matters, as firms base their entry decision on expected tax rates. For firms that exit the realized tax base share of immobile firms matters, as firms can postpone their relocation until the tax rate has actually been increased.

Our paper contributes to several lines of literature. First, our paper relates to the literature that points out a time-consistency problem in capital taxation. A first contribution by Kydland and Prescott (1980) shows that the anticipation of future high tax rates imposes an excess burden today. In this setting, ex-post optimal taxation implies a excessively high tax rate in the first period. Kehoe (1989) adds tax competition to the analysis and shows that its tendency to lower tax rates may thus be beneficial. Janeba (2000) models a firm that over-invests in capacity in two countries. As the firm then holds more capacity than required to satisfy demand, it induces tax competition between the countries, which then set very low tax rates. We contribute to this literature by showing that a sufficiently large share of highly mobile firms in a jurisdiction also alleviates the commitment problem. Further, our empirical work confirms that the costs of the commitment problem can be substantial and highlights that they should be taken into account when designing optimal taxes or subsidies for location sensitive industries such as renewable energies.

A second related literature discusses the dynamic effects of tax rate increases. The key trade-off is between generating more revenue from the existing tax base, or attracting a larger stock of capital, which can be taxed in the future (Wildasin, 2003). Marceau et al. (2010) show that countries with relatively little immobile capital will lower their tax rates to attract new, mobile capital, while such a strategy is too costly for countries with high stocks of immobile capital. Similarly, our paper studies the revenue-maximizing taxation of firms with different mobility, but we focus on the ex- 
post optimal tax rates. ${ }^{4}$ Empirically, Carlsen et al. (2005) show a negative relation between mobility (measured by profit variability of industrial sectors) and fees for infrastructure services across Norwegian municipalities. ${ }^{5}$ In contrast, we use a direct shock to average firm mobility and also analyse whether firms anticipate future tax rate changes.

Further papers studying the dynamic effects of capital taxes assume that existing capital and new capital can be taxed at different rates. Doyle and Van Wijnbergen (1994) show that tax holidays may occur as the result of sequential bargaining between a multinational firm and a host-country government. Bond and Samuelson (1986) point out that host countries may offer tax holidays to signal their productivity to multinational firms. Only a high-productivity country can recoup the tax rebates in the future, thus, offering a tax holiday signals that a country is a high-productivity location. In practice, setting firm-specific taxes is difficult, especially when the firms are small relative to the size of the economy. Therefore, we focus on a setting where all firms are taxed at the same rate, and firms' expectations about the tax rate thus depend on their expectations about the mix of the tax base.

Third, we add to the literature that studies the role of expectations for firm investment. Previous literature has shown that overall investor sentiment (Arif and Lee, 2014) and the expectations of both analysts (Cummins et al., 2006) and Chief Financial Officers (Gennaioli et al., 2015) have high predictive power for firm investment. Greenwood and Hanson (2015) highlight the importance of expectations for investment in the shipping industry. In contrast to these studies, which rely on surveys, analyst forecasts or current profits to measure expectations, we explicitly model expectations about future circumstances (in our case, tax rates).

Lastly, we contribute to the literature that considers the tax sensitivity of firms' location decisions. A higher tax burden on profits, due to higher tax rates or less

\footnotetext{
${ }^{4}$ Only few other papers have modelled government's tax rate choice in an economy in which firms with different mobility coexist. Haupt and Krieger (2013) set up a two-period model in which governments first compete in subsidies to attract firms, and then compete in taxes to avoid firm relocation. They find that higher relocation mobility increases net tax revenue, as the resulting fall in subsidy competition overcompensates the intensified tax competition. Becker and Schneider (2017) study a situation in which the share of mobile firms is unknown ex-ante. The government can use tax-induced firm migration to learn about the true number of mobile firms, so that it can set an optimal tax rate in the future.

${ }^{5}$ The empirical literature also shows the importance of further determinants of tax rates, e.g. agglomeration and urbanization rents or budget needs (e.g. Jofre-Monseny, 2013; Koh et al., 2013).
} 
generous depreciation rules, deters firms from locating in a particular jurisdiction (de Mooij and Ederveen, 2008; Feld and Heckemeyer, 2011; Zwick and Mahon, 2017). Some forces, such as agglomeration benefits, affect how sensitively firms react to the tax rates (Baldwin and Krugman, 2004; Borck and Pflüger, 2006; Brülhart et al., 2012). We contribute to this literature by showing that firms also consider future tax rates in their location decisions.

This paper proceeds as follows. Section 2 provides a theoretical model of firms' location decisions and the governments' tax rate choices. Section 3 introduces our identification strategy and provides some background information on the renewable energy sector in Germany. Section 4 analyses how municipalities react to a larger share of immobile firms. Section 5 studies whether firms anticipate the municipalities' behavior using a reduced-form approach as well as an instrumental variables strategy. Section 6 concludes.

\section{Model}

To clarify the effects at work, we first provide a stylized model. There are two countries in the model. The home country is a federation with $M$ local governments (e.g. provinces or municipalities), and each local government chooses its own tax rate, $\tau$. The other country has a low, uniform tax rate, $\tau_{l o w}$. The situation we want to capture with this set-up is that of a large federation and a nearby low-tax country to which firms can relocate. There are two types of firms, mobile firms (which can relocate to the low-tax country at a cost), and immobile firms (which cannot relocate). There are no immobile firms in the low-tax country. We assume that each local jurisdiction has to tax both mobile and immobile firms at the same rate. This assumption captures the empirical reality, especially for small- and medium sized firms. ${ }^{6}$

Mobile firms realize a fixed profit of $\pi^{M}$. A mass of potential entrants (normalized to 1 ) has the option to enter in a specific jurisdiction. Firms decide only about whether to enter or not, they cannot decide to enter in a different jurisdiction ("latent start-

\footnotetext{
${ }^{6}$ Preferential rates for mobile firms are difficult to implement. While some very large firms can negotiate special treatment, this route is not available to small- and medium sized firms. The European Union even prohibits preferential rates for individual firms as a form of illegal state aid.
} 
up model"). ${ }^{7}$ Mobile firms can, however, relocate to the foreign low-tax country later on. To enter, each firm has to pay a firm-specific fixed cost, $f_{i} \pi^{M}$, with $f_{i}$ following a uniform distribution in $[0,1]$. If a firm decides to relocate to the low-tax country, it has to pay the same fixed cost $f_{i} \pi^{M}$ to build a new plant there.

Immobile firms use a different technology which makes them unable to relocate (because they are bound to resources that exist only in the specific jurisdiction, or because the cost of relocation is prohibitively high). Examples could be mining companies, other resource extractors, or wind turbines. An immobile firm realizes a profit of $\pi^{I}$. Immobile firms have a fixed set-up cost of $c_{j}$ when they become active, with $c_{j}$ uniformly distributed in $[0,1]$. Only one immobile firm may be active in each jurisdiction. This normalization enables us to focus on the share of mobile vs. immobile firms later on and allows us to abstract from the size of the jurisdiction.

The model proceeds in five stages (see Figure 1). In the first stage, mobile and immobile firms decide whether to enter the market. These entry decisions may take place simultaneously or sequentially; in any case, the mobile firms do not know whether an immobile firm will enter. In the second stage, the local governments set their tax rates, observing which firms are active in each jurisdiction. This ordering of the stages of the game reflects that governments can adjust the tax rate after firms have entered: For example, in the empirical study presented below, a municipality is able to change its tax rate as soon as an immobile firm has set up. In the third stage, the low-tax country observes the tax rates chosen by all jurisdictions in the federation, and then chooses its own tax rate. The low-tax country, as the smaller country, is more flexible than other jurisdictions and thus moves later. ${ }^{8}$ In the fourth stage, mobile firms may relocate after observing the tax rate. In the last stage, firms produce and pay taxes.

We solve the model backwards and start with the relocation decision of mobile firms. Mobile firms relocate if the after-tax profit in the local jurisdiction, $\left(1-\tau^{j}\right) \pi^{M}$, is lower than the profit they would realize when relocating to the low-tax country, $\left(1-\tau_{\text {low }}\right) \pi^{M}-f_{i} \pi^{M} . \tau^{j} \in\left\{\tau^{I} ; \tau^{0}\right\}$ denotes the tax rate that the government chooses in

\footnotetext{
${ }^{7}$ In other words, potential entrepreneurs are immobile. Entrepreneurs then sell a successful firm to an investor, who can decide to move the firm to the low-tax country (see e.g. Becker and Henderson, 2000; Brülhart et al., 2012). Using a sample of Portuguese firms, Figueiredo et al. (2002) show that indeed most entrepreneurs (72\%) start firms in their home district.

${ }^{8}$ With this assumption we follow the literature on Stackelberg tax comptition, see e.g. Gordon (1992), Wang (1999) or Altshuler and Goodspeed (2015).
} 
Figure 1: Game tree

$1^{\text {st }}$ stage:

Mobile firms

$2^{\text {nd }}$ stage:

$3^{\text {rd }}$ stage:

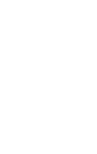

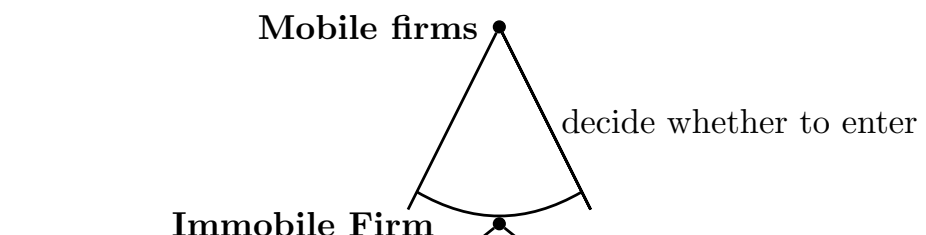

.

Low-Tax Country

$4^{\text {th }}$ stage:

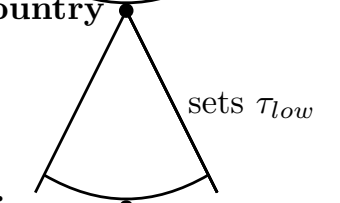

Mobile Firms
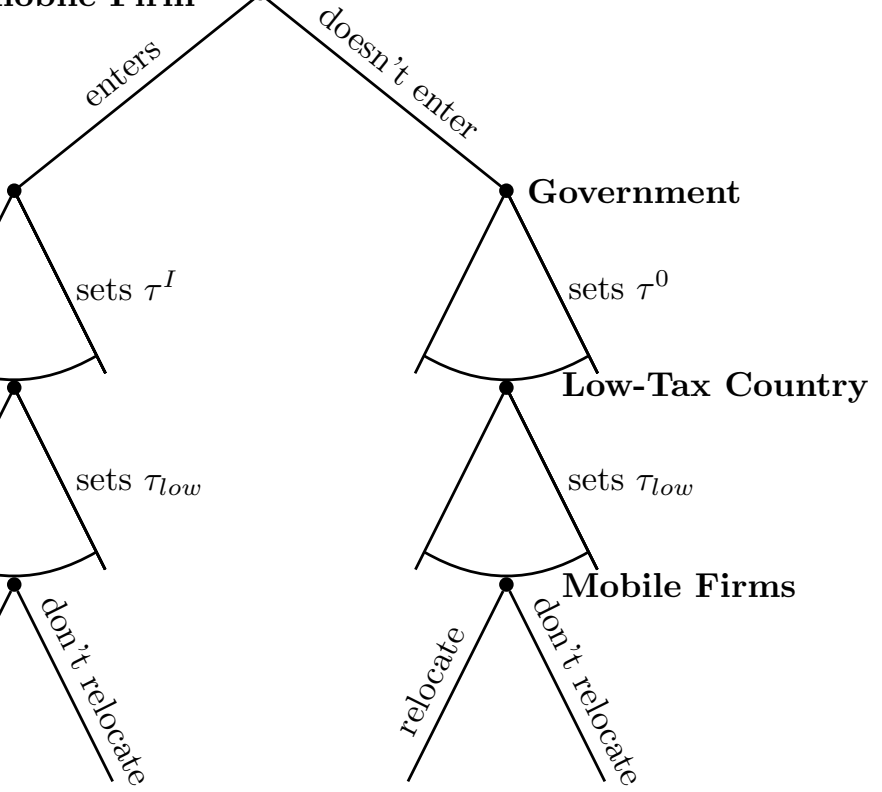

$5^{\text {th }}$ stage: Firms produce and pay taxes. 
the second stage ( $\tau^{I}$ if an immobile firm is active, $\tau^{0}$ if not). Those mobile firms with

$$
f_{i}<\tau^{j}-\tau_{\text {low }}
$$

relocate. The immobile firm cannot relocate by assumption.

As there are many local jurisdictions within the federation, they do not take into account the effect they have on the low-tax country's tax rate choice. We thus postpone the discussion of the low-tax country and continue by studying the tax rate decisions of the local governments. Each local government observes which firms have entered (in particular, whether an immobile firm has entered), and it anticipates the relocation decisions of mobile firms.

We assume that local governments set their tax rates to maximize tax revenues. Tax revenues depend on whether an immobile firm entered in the first stage:

$$
T= \begin{cases}\tau^{0}\left[\mu \pi^{M}-\left(\tau^{0}-\tau_{\text {low }}\right) \pi^{M}\right], & \text { if no immobile firm entered } \\ \tau^{I}\left[\pi^{I}+\mu \pi^{M}-\left(\tau^{I}-\tau_{\text {low }}\right) \pi^{M}\right], & \text { if an immobile firm entered }\end{cases}
$$

where $\mu$ is the mass of mobile firms that entered the jurisdiction in stage 1 , and the last term in the brackets describes the mass of mobile firms that relocates in stage 4 according to eq. (1).

The revenue-maximizing tax rates are

$$
\begin{aligned}
\tau^{0} & =\frac{\mu+\tau_{\text {low }}}{2} \\
\tau^{I} & =\frac{\pi^{I}+\pi^{M}\left(\mu+\tau_{\text {low }}\right)}{2 \pi^{M}}=\frac{\eta}{2}+\tau^{0},
\end{aligned}
$$

where $\tau^{I}$ depends on the potential tax base share of immobile firms, $\eta=\frac{\pi^{I}}{\pi^{M}}, \eta<1 .^{9}$ The tax rate rises in the tax base: $\tau^{0}$ increases with $\mu$, i.e. the number of active firms; $\tau^{I}$ rises in both $\mu$ and the potential tax base share of immobile firms, $\eta$. The optimal tax rate thus trades off the additional tax revenue of a higher tax rate (for a fixed number of firms) and the revenue loss from a larger number of firms relocating in response to the tax rate increase. As the second effect is smaller if an immobile firm is present, the government always chooses a higher tax rate if an immobile firm is active. Correspondingly, the mark-up in the tax rate if an immobile firm enters is higher when the potential tax base share of the immobile firm is higher.

\footnotetext{
${ }^{9}$ As the mass of potential mobile firms is normalized to $1, \pi^{M}$ corresponds to total profits of mobile firms.
} 
Firms anticipate the tax rates when they decide whether to enter or not. Mobile firms can only base their entry decision on an expected tax rate, $E(\tau)=p \tau^{I}+(1-p) \tau^{0}$, where $p$ is the probability that an immobile firm enters. In contrast, the immobile firm anticipates that if it enters, the jurisdiction will increase the tax rate to $\tau^{I}$ for sure. Therefore, the immobile firm enters only if $\pi^{I}\left(1-\tau^{I}\right) \geq c_{i} \pi^{I}$. Given that $c_{i}$ is uniformly distributed, $p$ is

$$
p=\left(1-\tau^{I}\right)=1-\frac{\mu+\eta+\tau_{\text {low }}}{2} .
$$

Mobile firms base their entry decision on the expected tax rate, and the mass of firms that enters is $\mu=1-E(\tau)$. We assume that $\eta$ is sufficiently small that not all mobile firms relocate after immobile firm entry. ${ }^{10}$ Using (3) and (4), and solving for $\mu$,

$$
\mu=\frac{4-2 \tau_{\text {low }}-\eta\left(2-\eta-\tau_{\text {low }}\right)}{6-\eta} .
$$

Let us now turn to the low-tax country. It observes the tax rates chosen by the $M$ local governments and anticipates the relocation decisions of mobile firms. It sets its tax rate to maximize its tax revenues, $T_{\text {low }}$. For simplicity, we assume that there are no other firms in the low-tax country. Tax revenues in the low-tax country then are

$$
T_{\text {low }}=\tau_{\text {low }} M\left[p\left(\tau^{I}-\tau_{\text {low }}\right)+(1-p)\left(\tau^{0}-\tau_{\text {low }}\right)\right]
$$

Maximizing eq. (6) yields the revenue-maximizing tax rate of the low-tax country,

$$
\tau_{\text {low }}=\frac{p \tau^{I}+(1-p) \tau^{0}}{2}
$$

The low-tax country thus sets a lower tax rate if the average tax rate in the home country is lower. The tax rates of the low-tax country and of the small jurisdictions of the home country are strategic complements, as common in models of tax competition.

We are now in position to describe the equilibrium in the model economy. Inserting eq. (7) in eq. (3), and using eqs. (4) and (5) yields the equilibrium tax rates of the local governments,

$$
\begin{aligned}
\tau^{0^{*}} & =\frac{8-\eta(2-\eta)}{2(10-\eta)} \\
\tau^{I^{*}} & =\frac{4(1+\eta)}{10-\eta}
\end{aligned}
$$

and for the low-tax country

$$
\tau_{\text {low }}^{*}=\frac{2+\eta-\eta^{2}}{10-\eta}
$$

\footnotetext{
${ }^{10}$ After solving for the equilibrium, we can show that this implies $6 \eta-\eta^{2}<4$.
} 
$\tau^{I^{*}}$ increases in the potential tax base share of immobile firms, $\eta$. A higher $\eta$ implies that the immobile firm has the potential to make up a larger share of the tax base. The local government thus has an incentive to choose a higher tax rate as less of its tax base moves away in response. The effect of $\eta$ on $\tau^{0^{*}}$ and $\tau_{\text {low }}$ is non-monotonic: For low and medium values of $\eta, \tau^{0^{*}}\left(\tau_{\text {low }}\right)$ falls (rises) in $\eta$; for high values of $\eta, \tau^{0^{*}}\left(\tau_{\text {low }}\right)$ rises (falls) in $\eta$.

To understand the effects at work, first imagine a world without immobile firms. Here, tax competition is intense. In the beginning, immobile firms alleviate the tax competition, as they allow the local governments to set higher tax rates on average. However, as $\eta$ rises, $\tau^{I}$ also rises. This makes market entry less attractive for all firms. For high levels of $\eta$, the commitment problem of local governments becomes stronger: Most immobile firms are deterred from entering by the fact that governments will set a very high tax rate after their entry. As governments cannot commit to keep tax rates low, immobile firms do not enter. A large number of mobile firms (low $\eta$ ) then helps to keep pressure on tax rates. Mobile firms anticipate the lower risk of a tax rate increase. Entry again becomes more attractive for them for high levels of $\eta$. Thus, tax competition increases again, implying a lower $\tau_{\text {low }}$. Note that while average tax rates fall for high levels of $\eta, \tau^{0^{*}}$ rises due to the increased entry of mobile firms. ${ }^{11}$

Proposition 1 (Equilibrium Tax Rates) A jurisdiction sets a higher tax rate $\left(\tau^{I^{*}}=\frac{4+4 \eta}{10-\eta}\right)$ if an immobile firm has entered, compared to an identical jurisdiction without an immobile firm $\left(\tau^{0^{*}}=\frac{8+\eta^{2}-2 \eta}{2(10-\eta)}\right) \cdot \tau^{I^{*}}$ increases in the potential tax base share of the immobile firm, $\eta$.

Proof. $\quad \tau^{I^{*}}, \tau^{0^{*}}$ follow from using eq. (4), (5) and (7) in eq. (3) and simplifying. $\tau^{I^{*}}>\tau^{0^{*}}$ as $\tau^{I^{*}}-\tau^{0^{*}}=\eta / 2$.

Next, we turn to equilibrium firm behavior. Firm entry in equilibrium is described by $p^{*}=\frac{6-5 \eta}{10-\eta}$ and $\mu^{*}=\frac{6-\eta(3-2 \eta)}{10-\eta}$. After mobile firms have relocated, there are $\mu_{R}^{j}{ }^{*}=$ $\mu-\left(\tau^{j}-\tau_{\text {low }}\right), j \in[0, I]$ firms remaining in each jurisdiction,

$$
\begin{aligned}
& \mu_{R}^{{ }^{*}}=\frac{8-\eta(2-\eta)}{2(10-\eta)} \\
& \mu_{R}^{I^{*}}=\frac{4-6 \eta+\eta^{2}}{10-\eta} .
\end{aligned}
$$

\footnotetext{
${ }^{11}$ That is, for high levels of $\eta$, both $\tau^{I}$ and $\tau^{0}$ rise, but $E(\tau)=p \tau^{I}+(1-p) \tau^{0}$ falls due to $p$ decreasing strongly with $\eta$ and $\tau^{0}$ being much lower than $\tau^{I}$. Note that $\tau^{I^{*}} \rightarrow 1$ if $\eta \rightarrow 1$.
} 
Thus, there are $\mu_{R}^{0 *}-\mu_{R}^{I *}=\eta / 2$ more firms active in a jurisdiction without an immobile firm.

Proposition 2 (Equilibrium Firm Behavior) In equilibrium, immobile firms are active in $p M=\frac{6-5 \eta}{10-\eta} M$ jurisdictions. These jurisdictions have fewer active mobile firms $\mu_{R}^{I *}=\frac{4-6 \eta+\eta^{2}}{10-\eta}$ than jurisdictions without an immobile firm $\left(\mu_{R}^{0 *}=\frac{8-\eta(2-\eta)}{2(10-\eta)}\right)$.

As local governments cannot commit to keep tax rates low after the immobile firm has entered, the probability of immobile firm entry falls in $\eta$.

Proof. Eq. (10) derives $\mu_{R}^{0 *}$ and $\mu_{R}^{I *} \cdot p$ falls in $\eta$ as $\frac{\partial p}{\partial \eta}=\frac{-56}{\left(10-\eta^{2}\right.}<0$.

The following corollary summarizes the market entry incentives for firms of both types for use in the empirical tests discussed in the following sections.

Corollary 1 (Firm Entry and Tax Rates) 1. The immobile firm's entry decision depends on $\tau^{I}$, i.e. the future tax rate which takes into account that the government will increase the tax rate after the immobile firm's entry.

2. Mobile firms' entry decisions depend on the expected future tax rate.

Mobile firms use all available information to estimate how the tax rate may develop in the future. In particular, given eq. (8), the potential tax base share of immobile firms determines by how much the tax rate may rise. Thus, mobile firms prefer to enter in jurisdictions with a low potential tax base share of mobile firms.

\section{Empirical Strategy}

\section{$3.1 \quad$ Setting}

Our model has two main implications: First, it finds that governments increase tax rates when an immobile firm enters a jurisdiction. Second, it shows that forward-looking mobile firms anticipate the likelihood of an immobile firm entering the jurisdiction and thus the potential future tax increase. In particular, the model implies that firms prefer to locate in jurisdictions with a low risk of immobile firm entries, as this decreases the likelihood of future tax rate hikes.

In the following, we empirically test these hypotheses. To do so, we exploit the evolution of a new and highly immobile industry within Germany. The setting within 
Germany is particularly suited for our research question, as it provides ample variation in tax rates without regulatory or tax base differences that could be problematic in a cross-country setting. In Germany, municipalities have the right to tax corporate profits. This local business tax accounts for roughly $50 \%$ of the tax burden on profits. In most of the over 11,000 municipalities, the tax rate is between $14 \%$ and $19 \%$, with a mean of $16 \%{ }^{12}$ Tax rates change annually in about $10 \%$ of municipalities (Fuest et al., 2017). Firms pay the tax in the municipality where the plant is located. ${ }^{13}$ While the municipalities decide about the tax rate, the federal government defines the tax base.

Our identification strategy relies on changes in the mobility of the tax base. To identify such changes, we consider the market entry of very immobile firms: wind turbines. At the beginning of our sample period in 1999, only few wind turbines existed in Germany (see Figure 2). The installed turbine capacity grew substantially over the following twelve years (see Figure 3). As a result, profits of wind turbines became a significant source of tax revenue for many rural municipalities. In municipalities with at least one wind turbine, on average about $22 \%$ of the local business tax revenue came from wind power generation between 1999 and 2011 (see Table 3 in Setion 4.1). Thus, the entry of these firms substantially changed the composition of the tax base.

Germany saw such strong growth in the number of wind turbines because it actively promoted them. In 2000, the federal government passed the Renewable Energy Act. This law introduced a price guarantee for green electricity in the form of a feed-in tariff to promote investment into renewable energies (as agreed in the Kyoto Protocol and in the Lisbon Treaty). The feed-in tariff guarantees a minimum wholesale price for wind energy for 20 years after the installation of the plant and thus made investments into wind power much more attractive. The average guaranteed price is about 8 cent per kWh, which substantially exceeds the average market price for electricity of about 3

\footnotetext{
${ }^{12}$ Municipalities do not choose the tax rate, but a "tax multiplier". To calculate the tax rate, one has to multiply the tax multiplier by $5 \%$ (before 2008) or $3.5 \%$ (from 2008 onwards). The 2008 reform also changed how the tax base is calculated; in particular, the local business tax was deductible from its own tax base before the reform.

${ }^{13}$ If a firm is active in several municipalities, usually the wage bill determines how much local business tax the firm pays in each municipality. However, for wind turbines and solar power stations, where most plants have zero employees, there is an alternative allocation method. It allocates $70 \%$ of the tax base to the municipality where the plant is located; the remaining $30 \%$ go to the headquarter's municipality (Par 29 Local Business Tax Law).
} 


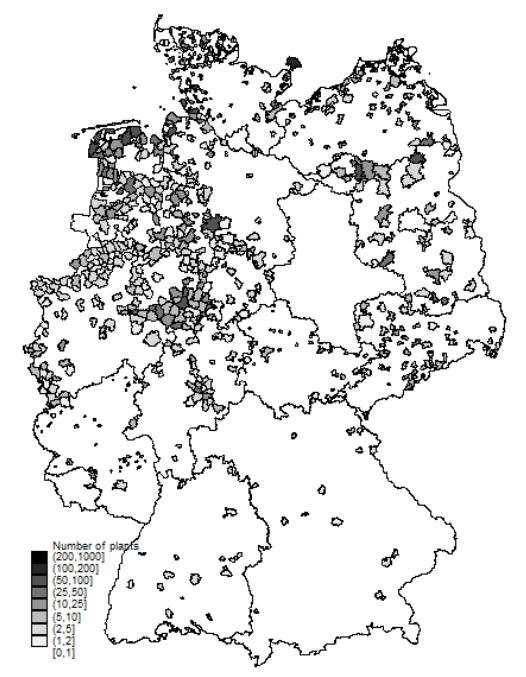

Number of wind turbines per municipality in 1999. Source: Authors' calculation based on data from the operator database, 1999.

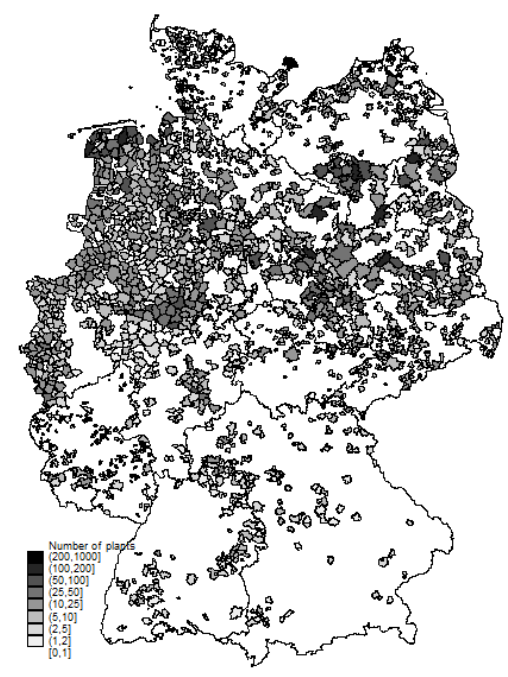

Number of wind turbines per municipality in 2011. Source: Authors' calculation based on data from the operator database, 2011.

cent per kWh (see Haan and Simmler, 2016). ${ }^{14}$ To finance this subsidy, all electricity consumers pay a share of their electricity bill into a fund. Although the generosity of the feed-in tariff decreased over time, profitability of newly built turbines stayed relatively constant or even increased over time due to technological development (see Figure 4).

The quick evolution of this new firm type is well-suited to our analysis: Wind turbines are very immobile, and their location decision is relatively simple. First, consider their immobility. It is extremely costly for wind turbines to relocate. Most of the investment is specific to the location of the investment. For example, local wind conditions strongly influence the choice of turbine technology. The actual cost of relocating is extremely high, even if an alternative location for which the particular technology is suited can be found. Land is often bought or leased with a very long contract. ${ }^{15}$

Second, consider their location decision. By far the most important location specific factor is wind strength. In addition, agricultural land prices and local business taxes

\footnotetext{
${ }^{14}$ A subsidized feed-in tariff had existed in Germany since 1992, but in these early years the tariff was lower (it was set to $90 \%$ of the end-consumer price). In addition, its duration was uncertain, as it was only paid for as long as the law was in effect. The new, higher feed-in tariff was introduced in 2000. Note that it decreases slightly over time and was adjusted downward in 2004 and 2009.

${ }^{15}$ As the lifetime of a wind turbine is 20 years, lease contracts are commonly concluded for 20 years.
} 
Figure 4: Evolution Wind Turbine Profitability

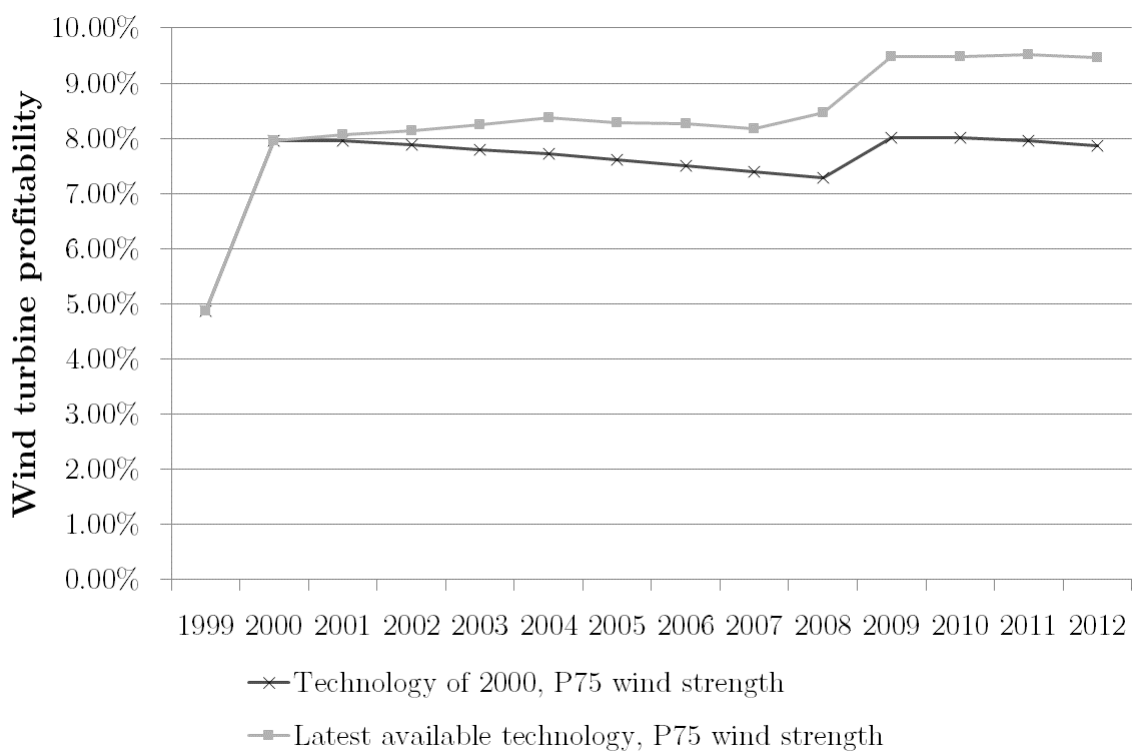

This figure depicts the evolution of expected wind turbine profitability for the 75th percentile of wind strength, using the latest available technology and the technology in 2000. We calculate the profitability of a wind turbine as expected profit over costs. We define the latest available technology as the median technology of wind turbines built in that year. For more information see Haan and Simmler (2016). Source: Authors' calculation based on data from the operator database, 1990 to 2011.

matter (Ross and Carley, 2016).${ }^{16}$ Differences in wage costs are not important as almost no labor is involved in wind electricity generation. As the electricity grid in German is well developed, distances to the main power lines play little role. Given the limited number of determinants for wind turbines' location decision, municipalities have few options to attract wind turbines, except for the local business tax rate. In particular, municipalities may not pay specific subsidies for wind power generation and states (not municipalities) regulate where wind turbines may be built.

\subsection{Data}

In our empirical analysis, we use panel data at the municipality level. The dataset includes information on the tax rate and tax base, information on firm entries, as well as several municipality and regional characteristics. The sample for the analysis

\footnotetext{
${ }^{16}$ Wind turbines are usually on agricultural land as regulation requires a minimum distance to populated areas.
} 
of municipalities' tax rate choice includes the years from 1998 to $2011 .{ }^{17}$ We end our sample period in 2011, as in 2012 the German government introduced a premium for directly sold green electricity. As we do not observe who the electricity was sold to, we cannot model this premium. The sample for the analysis of firms' location decisions includes the years from 1998 to 2006. In 2008 Germany reduced the corporate tax rate and broadened the tax base. As this affects the impact of the local business tax on firms' location decisions, it limits comparability over time.

Table 1: Variable definitions and sources: Municipalities' tax rate choices (1999 to 2011)

\begin{tabular}{|c|c|c|}
\hline Variable & Definition & Source \\
\hline $\begin{array}{l}\text { Local business tax multi- } \\
\text { plier (LBTM) }\end{array}$ & $\begin{array}{l}\text { LBTM set by municipality in the begin- } \\
\text { ning of each year. }\end{array}$ & Statistik Lokal \\
\hline Local business tax base & $\begin{array}{l}\text { Tax base for the local business tax } \\
(\approx \text { profits plus part of financing costs }) .\end{array}$ & Statistik Lokal \\
\hline Population & Population of the municipality. & Statistik Lokal \\
\hline Agricultural land & Agricultural land in hectares. & Statistik Lokal \\
\hline Wind strength & $\begin{array}{l}\text { Average wind strength } 80 \mathrm{~m} \text { above } \\
\text { ground in meters per second between } \\
1981 \text { and } 2000 \text {. }\end{array}$ & $\begin{array}{l}\text { Calculation based on } \\
\text { square kilometer grid } \\
\text { data from the German } \\
\text { Weather Service using } \\
\text { SAGA }\end{array}$ \\
\hline $\begin{array}{l}\text { Realized tax base share } \\
\text { immobile firms (IF) }\end{array}$ & $\begin{array}{l}\text { Ratio of built wind turbines' tax base to } \\
\text { total tax base (tax base in } 1998 \text { plus built } \\
\text { wind turbines' tax base). }\end{array}$ & $\begin{array}{l}\text { Simulation based on data } \\
\text { from Operator Database, } \\
\text { German Weather Service } \\
\text { and financial statements } \\
\text { database DAFNE }\end{array}$ \\
\hline Agricultural land price & $\begin{array}{l}\text { Average agricultural land price per } \\
\text { hectare, county level. }\end{array}$ & $\begin{array}{l}\text { Federal Statistical Offices } \\
\text { of the Laender }\end{array}$ \\
\hline Neighbor LBTM & $\begin{array}{l}\text { Average LBTM in municipalities within } \\
20 \mathrm{~km} \text { radius. }\end{array}$ & $\begin{array}{l}\text { Calculation based on } \\
\text { Statistik Lokal }\end{array}$ \\
\hline
\end{tabular}

All variables are at the municipality level except the agricultural land price (county level).

\footnotetext{
${ }^{17}$ In all states in former East Germany, administrative reforms took place after 1990 to reduce the number of municipalities. In our sample, $7 \%$ of all municipalities partake at least once in a municipality merger. To increase comparability over time, we treat changes in administrative borders during our sample period as if they had occurred at the beginning of the sample period. We construct the premerger tax rate in these cases as a population weighted average of the tax rates. When we exclude the two states with the most mergers (Brandenburg and Saxony-Anhalt) from the analysis, we find very similar results.
} 
Our model points out that the tax base share of wind turbines matters. In the remainder of the paper, we use two conceptualisations of this tax base share: The realized and the potential tax base share. We expect that municipalities increase their tax rate after immobile firms have entered, i.e. in response to the realized tax base share of immobile firms. In contrast, mobile firms base their entry decision on expected future tax rates; thus, for them the potential tax base share matters.

To calculate the realized tax base share of immobile firms, we divide the tax base of built wind turbines by the overall tax base in 1998 plus the tax base of wind turbines. ${ }^{18}$ We add the tax base of wind turbines built up to $t-1$ to the denominator so that our measure is always between zero and one, reducing noise in the ratio. When considering municipality decisions in year $t$, we always use the tax base from wind turbines built up to $t-1$, as municipalities observe the tax base only in the year after the profits have been realized. ${ }^{19}$ We will show in sensitivity analyses that the results are not sensitive to the way of measuring the immobile firms' tax base share. Since we do not observe the tax base of built wind turbines we simulate this variable using data on wind turbines from the operator database. This is a private database, collected by consultants in the renewable energy industry and the chamber of agriculture in the state Schleswig-Holstein. The data set includes information on the location, technology and construction date of all wind turbines in Germany. We simulate wind turbines' profitability by using information on the average wind strength in a municipality and the feed-in tariff that applied in the respective year (see Haan and Simmler, 2016, for details of this calculation). The simulated tax base varies over time as new turbines are built and their taxable profits change due to changes in the feed-in tariff, capital allowances, or bank financing. We assess the predictive power of the simulation by regressing the observed total local business tax base on our simulated wind turbines tax base. The results, shown in Table A1 in Appendix A, suggest that the estimated

\footnotetext{
${ }^{18}$ Ideally, we would like to use as the denominator what the tax base of mobile firms would have been if no mobile firm had entered. We approximate this hypothetical tax base by using the 1998 tax base. In a robustness check, we also used a predicted tax base based on the number of inhabitants in a jurisdiction. Results are similar and available from the authors upon request.

${ }^{19}$ Municipalities do not assess the local business tax base themselves. Instead, regional authorities assess the tax base. Due to these two institutions being involved, firms usually pay the local business tax in the following year.
} 
coefficient is close to one and significant at the $1 \%$ level. $^{20}$

To calculate the potential tax base share of immobile firms, we proceed in three steps. First, we determine the expected profitability of a wind turbine in a certain municipality and year. Second, we estimate the potential number of wind turbines in that municipality. Third, we divide the estimated potential tax base of wind turbines by a measure of the overall tax base.

Regarding the first step, we use the same method to simulate the tax base of wind turbines as above, but using the median technology of new wind turbines. We then take the average profit over the life cycle of the turbine. Regarding the second step, we need to make an assumption about a reasonable maximum of wind turbines that can be built in a jurisdiction. We assume that turbines will be built on $15 \%$ of the agricultural land, which corresponds to the 99th percentile of wind turbines per hectare of agricultural land in 2006. We will show in a sensitivity analysis that the results do not hinge on the reference to the agricultural land by using an estimate for the absolute number of wind turbines (again the 99th percentile of wind turbines per municipality in 2006). ${ }^{21}$ Regarding the third step, we scale the potential tax base of wind turbines by the tax base of mobile firms in 1998 plus the simulated potential wind turbine tax base. The variation used in the estimations thus stems only from the introduction of the Renewable Energy Act in combination with variation in wind strength across municipalities and level differences in the tax base of mobile firms before the introduction of the Renewable Energy Act.

In Section 4 we will use the realized tax base share to study municipalities' tax rate choice. In Section 5 we will use the potential tax base share to study the entry of new firms. The data on firm entry stems from the Gewerbeanzeigenstatistik, the registry of firms in Germany. It covers all firm entries and exits (including new establishments) in a particular municipality per year and discloses as well whether firms relocated or are newly founded. Further, it includes information on a firm's industry. The data covers the years 1998 to 2006 for almost all German states (in Hesse, the coverage only starts in 2000). We use information starting in 1999, as our tax base measure uses 1998 as

\footnotetext{
${ }^{20}$ The estimated coefficient is slightly larger than one when using the full sample. When excluding municipalities with a local business tax base in 1998 in the top or bottom $1 \%$ the coefficient decreases to 0.9 (col. 2).

${ }^{21}$ Note that the estimated number of turbines is fixed over the entire sample period. Varying the potential number of turbines would introduce only the same variation as changes in wind turbine profitability.
} 
the base year.

In our main tests, we will consider only "real" firm births. We do not include firm entries due to relocations, as the impact of municipality characteristics on new and already existing firms' location decisions likely differs (e.g. due to lower failure rates of existing firms, current and future tax rates should matter more for these firms). We also exclude the start of self-employment. ${ }^{22}$

Table 1 and 2 describe all variables and data sources used in Section 4 and 5, respectively.

Table 2: Variable definitions and sources: Firm entry decisions (1999-2006)

\begin{tabular}{|c|c|c|}
\hline Variable & Definition & Source \\
\hline Number of new firms & $\begin{array}{l}\text { All newly founded firms, excluding self- } \\
\text { employed. }\end{array}$ & Gewerbeanzeigenstatistik \\
\hline $\begin{array}{l}\text { Number of firm entries } \\
\text { due to relocation }\end{array}$ & $\begin{array}{l}\text { Entries of firms relocating from another } \\
\text { municipality. }\end{array}$ & Gewerbeanzeigenstatistik \\
\hline $\begin{array}{l}\text { Number of firm exits due } \\
\text { to relocation }\end{array}$ & $\begin{array}{l}\text { Exits of firms relocating to another munic- } \\
\text { ipality. }\end{array}$ & Gewerbeanzeigenstatistik \\
\hline Local Business Tax (LBT) & $\begin{array}{l}\text { Local business tax multiplier multiplied by } \\
5 \% \text { (before } 2008 \text { ) or } 3.5 \% \text { (from } 2008 \text { on- } \\
\text { wards) to yield local business tax rate. }\end{array}$ & Statistik Lokal \\
\hline $\begin{array}{l}\text { Potential tax base share } \\
\text { IF }\end{array}$ & $\begin{array}{l}\text { Ratio of potential wind turbines' tax base } \\
\text { to tax base in } 1998 \text { plus potential wind tur- } \\
\text { bines' tax base. Potential wind turbines are } \\
\text { defined as the number of turbines build on } \\
15 \% \text { of the agricultural land in the munic- } \\
\text { ipality. }\end{array}$ & $\begin{array}{l}\text { Simulation using data } \\
\text { from Operator Database, } \\
\text { German Weather Service } \\
\text { and financial statements } \\
\text { database DAFNE }\end{array}$ \\
\hline Realized tax base share IF & $\begin{array}{l}\text { Ratio of built wind turbines' tax base to } \\
\text { tax base in } 1998 \text { plus built wind turbines' } \\
\text { tax base. }\end{array}$ & $\begin{array}{l}\text { Simulation using data } \\
\text { from Operator Database, } \\
\text { German Weather Service } \\
\text { and financial statements } \\
\text { database DAFNE }\end{array}$ \\
\hline Spending in million euro & $\begin{array}{l}\text { Overall municipality and pro-rata county } \\
\text { spending excluding spending for social ser- } \\
\text { vices. }\end{array}$ & Jahresrechnungsstatistik \\
\hline Population & Population & Statistik Lokal \\
\hline
\end{tabular}




\begin{tabular}{|c|c|c|}
\hline $\begin{array}{l}\text { Neighbor spending in mil- } \\
\text { lion euro }\end{array}$ & $\begin{array}{l}\text { Sum of spending of neighboring municipal- } \\
\text { ities within } 20 \mathrm{~km} \text { radius. }\end{array}$ & $\begin{array}{l}\text { Calculation based } \\
\text { Statistik Lokal }\end{array}$ \\
\hline Neighbor LBT & $\begin{array}{l}\text { Average } \mathrm{LBT} \text { of neighboring municipalities } \\
\text { within } 20 \mathrm{~km} \text { radius. }\end{array}$ & $\begin{array}{l}\text { Calculation based } \\
\text { Statistik Lokal }\end{array}$ \\
\hline $\begin{array}{l}\text { Neighbor population (in } \\
1,000)<20 \mathrm{~km}\end{array}$ & $\begin{array}{l}\text { Sum of population of neighboring munici- } \\
\text { palities within } 20 \mathrm{~km} \text { radius. }\end{array}$ & $\begin{array}{l}\text { Calculation based } \\
\text { Statistik Lokal }\end{array}$ \\
\hline $\begin{array}{l}\text { Neighbor population (in } \\
1,000) 20 \mathrm{~km}<<40 \mathrm{~km}\end{array}$ & $\begin{array}{l}\text { Sum of population of municipalities more } \\
\text { than } 20 \mathrm{~km} \text { and less } 40 \mathrm{~km} \text { away. }\end{array}$ & $\begin{array}{l}\text { Calculation based } \\
\text { Statistik Lokal }\end{array}$ \\
\hline Area & Area in hectares. & Statistik Lokal \\
\hline Agricultural land & Agricultural land in hectares. & Statistik Lokal \\
\hline Number of students & $\begin{array}{l}\text { Number of students per 1,000 inhabitants, } \\
\text { county level. }\end{array}$ & INKAR ( inkar.de) \\
\hline Unemployment rate & Unemployment rate, county level. & INKAR \\
\hline Doctors & $\begin{array}{l}\text { Number of doctors per } 100,000 \text { inhabi- } \\
\text { tants, county level. }\end{array}$ & INKAR \\
\hline
\end{tabular}

Calculations described in Section 3.2 in detail. All variables are at the municipality level unless stated otherwise.

\section{Municipality Level: Tax Rate Choice and Immo- bile Firms}

In this section, we provide evidence that municipalities increase the tax rate on firm profits if the tax base in the municipality becomes less mobile, that is, when the tax base share of immobile firms rises.

\subsection{Sample and Descriptive Evidence}

It is important for our identification strategy that the arrival of wind turbines is random, given the control variables. To ensure that this is the case, we select the municipalities in our sample with a propensity score matching approach, matching on the probability that at least one wind turbine is built in the respective municipality. Our treatment group are municipalities with at least one wind turbine in 2011; the control group does not have wind turbines in 2011. We match on the average (time-constant) wind strength 80 meter above ground, the natural logarithm of the agricultural land 
price $^{23}$, the natural logarithm of agricultural land area, the natural logarithm of the local business tax base in 1998, the natural logarithm of the population in 1998, and the local business tax multiplier in 1998. We employ the one to one nearest neighbor matching method. Table A2 in the Appendix provides descriptive statistics for the treatment and control group before and after the matching, suggesting that the observable characteristics in the matched sample are similar for treatment and control group municipalities.

Table 3 shows descriptive statistics based on the matched sample. The average local business tax multiplier between 1999 and 2011 is 339 points, which translates to a tax rate of roughly $15 \%{ }^{24}$ The average population in our sample is 12,717 . The average tax base share of immobile firms is $7 \%$, and for the subset of municipalities with at least one wind turbine, it is $22 \%$.

Table 3: Descriptive Statistics Municipality Level 1999 to 2011

\begin{tabular}{lccccccc}
\hline & \multicolumn{3}{c}{ All municipalities } & \multicolumn{3}{c}{$\begin{array}{c}\text { Municipalities with at } \\
\text { least 1 wind turbine }\end{array}$} \\
& Mean & P50 & SD & Mean & P50 & SD \\
\hline Local business tax multiplier & 339.43 & 330.00 & 40.71 & 347.49 & 340.00 & 43.86 \\
Wind strength 80m above ground & 5.57 & 5.48 & 0.64 & 5.80 & 5.73 & 0.63 \\
Realized tax base share IF & 0.07 & 0.00 & 0.20 & 0.22 & 0.05 & 0.30 \\
Population & 12,717 & 4,047 & 46,169 & 15,904 & 5,689 & 46,148 \\
\hline Observations & & 53,898 & & & 18,378 & \\
\hline
\end{tabular}

Notes: Mean, median and standard deviation for municipality characteristics. IF stands for immobile firms.

Source: Authors' calculation based on Statistik Lokal, 1999 to 2011, data from the operator data base, 1990 to 2011, and data from the German Weather Service.

We first report descriptive evidence on the relationship between the local business tax multiplier and the tax base share of immobile firms. In Figure 5, we plot the kernel density for the changes of the local business tax multiplier between 1999 and

\footnotetext{
${ }^{23}$ We do not have land prices at the municipality but only at the county level. Further, for some municipalities no prices are reported due to low transaction numbers. We impute the missing price information using neighboring county land prices.

${ }^{24}$ More precisely, to $17 \%$ before 2008 and $12 \%$ after 2007 . To derive the tax rate, the multiplier is multiplied with a base rate, which was changed in 2008. The 2008 reform is also reason why we use the local business tax multiplier. Results based on the final tax rate are very similar and available upon request.
} 
Figure 5: Kernel Density for Local Business Tax Multiplier Changes for Municipalities With and Without Wind Turbines

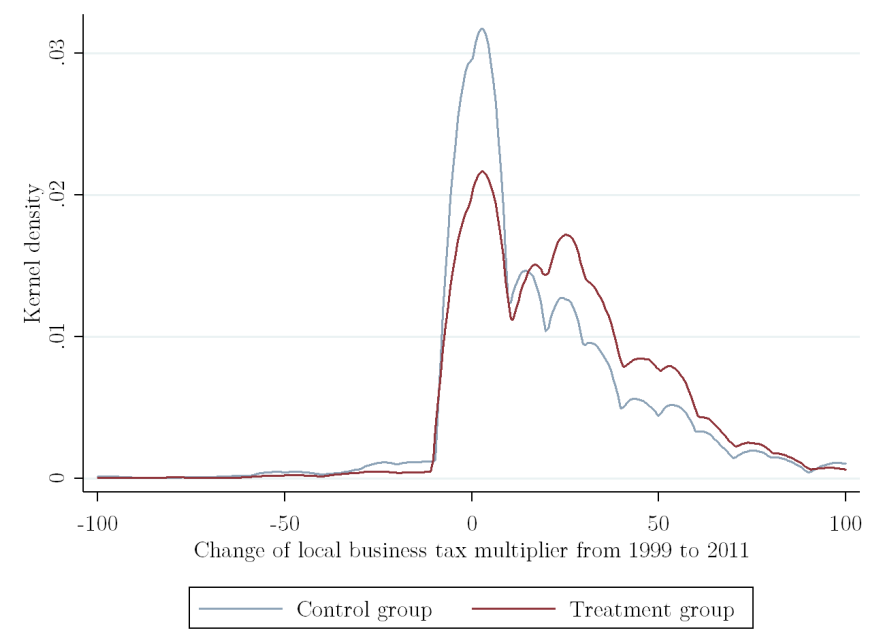

Notes: Treatment group includes municipalities with wind turbines in 2011, control group includes municipalities with similar characteristics as the treatment group but without wind turbines in 2011. Control groups municipalities are selected using propensity score matching.

Source: Authors' calculation based on Statistik Lokal 1999 to 2011 and data from the operator database 1990 to 2011 .

2011. The figure suggests that municipalities with at least one wind turbine in 2011 (treatment group) were more likely to increase their tax rate between 1999 and 2011 compared to municipalities with no wind turbines in 2011 (control group). Figure 6 shows the average change in the local business tax multiplier between 1999 and 2011 for municipalities which were impacted differently by the increase in wind turbines. To do so, we split the sample into five quintiles based on the change in the tax base of immobile firms in each municipality. The resulting figure shows that municipalities with larger changes in the tax base share increased their local business tax multiplier to a larger extent.

\section{$4.2 \quad$ Regression Evidence}

We estimate the following linear specification using the above outlined matched sample to provide further evidence that municipalities increase the tax rate when the tax base share of immobile firms rises: 
Figure 6: Changes of Local Business Tax Multiplier for Different Intervals of Changes of the Tax Base Shares of Immobile Firms

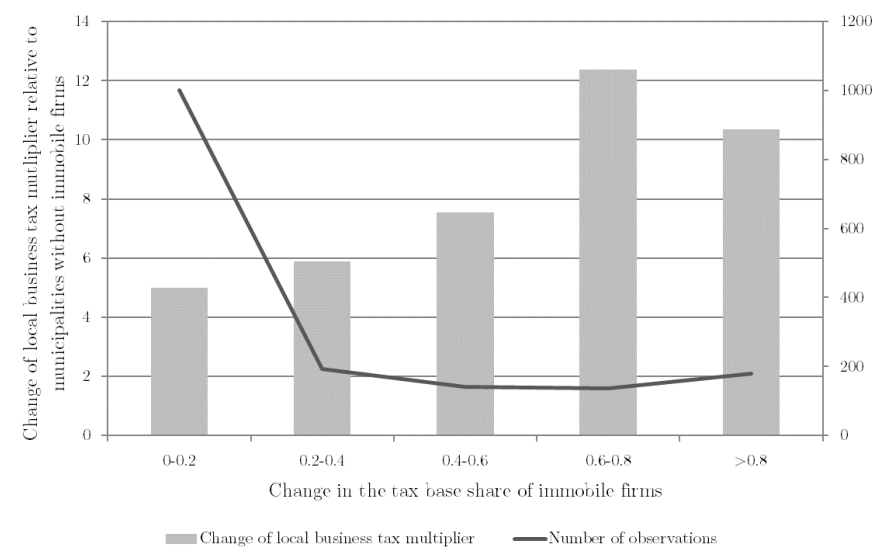

Notes: The bars indicate the change in the local business tax multiplier between 1999 and 2011, the line the number of municipalities within the respective group of changes in the tax base share of immobile firms between 1999 and 2011.

Source: Authors' calculation based on Statistik Lokal, 1999 to 2011, and data from the operator database, 1990 to 2011, and the German Weather Service.

$$
\tau_{i, t}=\alpha \frac{T_{I, i, t}^{R}}{T_{0, i, t}}+\beta^{\prime} X_{i, t}+\rho_{t}+\delta_{i}+\epsilon_{i, t} .
$$

The dependent variable $\tau_{i, t}$ is the local business tax multiplier in municipality $i$ at time $t$. In the most simple specification, we regress it on the tax base share of immobile firms $\left(\frac{T_{I, i, t}^{R}}{T_{0, i, t}}\right)$, a municipality specific effect $\left(\delta_{i}\right)$, and a full set of time dummies $\left(\rho_{t}\right) \cdot{ }^{25}$ In additional specifications, we further account for time-varying municipalities characteristics $\left(X_{i, t}\right)$. These include the natural logarithm of the population, the share of the population under 5 and over 65 years, and the share of the political parties in the community council. ${ }^{26}$ Moreover, we include in additional specifications state-year fixed effects to absorb any potential impact of state-specific fiscal equalization schemes (which affect municipalities' tax rate choice) and to account for the fact that states

\footnotetext{
${ }^{25}$ The inclusion of municipality-fixed effects is necessary to avoid biased results as our matching strategy only accounts for time-invariant differences (based on observable characteristics) between municipalities with and without turbines in 2011. Our estimation strategy, however, exploits also variation among municipalities with turbines in 2011.

${ }^{26}$ Although some of the control variables may be endogenous, the IV approach discussed below addresses the resulting bias. In a sensitivity check, we excluded the control variables. Point estimates are somewhat smaller but not statistically different from the results presented.
} 
can influence the location of wind turbines with state-wide land use plans. We report heteroscedasticity-robust standard errors clustered at the municipality level. ${ }^{27}$

There are three potential problems when estimating specification (11). First, the timing may be misspecified as we currently assume that municipalities increase their tax rates immediately. Second, there is an endogeneity problem as the tax rate in the municipality influences the number of wind turbines. Third, as we have to simulate the tax base of wind turbines, there is measurement error in our variable of interest.

To address the outlined challenges, we use an instrumental variable estimator. Our excluded instrument mirrors the tax base share using exogenous variables. To capture the numerator of the tax base share (the wind turbines's tax base), we use the interaction between the amount of agricultural land and a reform dummy capturing the introduction of wind turbine subsidies. To take the variation in the denominator (the total tax base) into account, we divide this measure by the sum of urban, agricultural and industrial land. ${ }^{28}$ To rule our that a different impact of the amount of agricultural land and/or wind strength after 2000 drive our results, we include additional control variables in the second stage. These control variables are the interaction between the logarithm of agricultural land and the reform indicator, as well as the interaction between wind strength and the reform indicator. Variation in our excluded instruments stems from the interaction between land use and wind strength.

Table 4 reports the results. The point estimate when using all years between 1999 and 2011 and including municipality as well as year fixed effects is 5.8 (col. 1). In specification (2) we include all other control variables except for state-year fixed effects. The point estimate is similar. In col. (3), we account in addition for state-year fixed

\footnotetext{
${ }^{27}$ Due to the matching strategy, these standard errors are not correct. However, since it has been shown that standard bootstrapping is not valid in this case either (Abadie and Imbens (2008)), we report heteroscedasticity-robust standard errors and show that the point estimate as well as the precision of the estimate are almost unchanged when using the full sample.

${ }^{28}$ In principle, we could use the information separately to construct two instruments (one for the numerator and one for the denominator). However, variation in the amount of agricultural land, which is central for the strength of the instrument for the numerator (the tax base of immobile firms), is limited, as agricultural land is included in our set of matching variables. When we use two separate instruments, results are similar in the matched sample; however, the instrument for the numerator is insignificant in the first stage. In a sensitivity analysis we will show that the results are similar when using both instruments separately in the full sample. In both the full and the matched sample, we test the overidentifying restriction. In both tests, the null is not rejected, giving some indication that our instrument is valid.
} 
effects and the coefficient decreases slightly to 4.0. In col. (4), we only use the years 1999 and 2011 - which is equivalent to using a 12-year difference estimator - to relax the assumed timing between the arrival of wind turbines and the tax rate change. The coefficient increases to 7.0 and is significant at the $1 \%$ level.

To address the endogeneity of the tax base measure as well as the measurement error, we use the instrumental variable estimator from col. (5) onwards. The F-statistic confirms that our preferred instrument has good explanatory power. We report the point estimate for our excluded instrument in the first stage equation at the bottom of the table. Using the instrumental variable estimator, the coefficient in col. (5) continues to be positive and highly significant. The estimate is now 41.9, indicating that the OLS results were indeed biased. In col. (6), we include the neighbor business tax multiplier to control for a possible spatial correlation of tax rates. Since the neighbor tax rate may also be endogenous, we use the same instruments as for the tax base share. The estimated coefficient of interest changes only slightly. The size of the coefficient for the neighbor tax rate is somewhat smaller than prior results in the literature (e.g. Devereux et al., 2008; Koh et al., 2013) but not very precisely estimated.

Based on the IV estimation in our preferred specification shown in col. (6), our results suggest that municipalities increase the business tax rate multiplier (and thus the tax rate on business profits) by about $12 \%$ if the tax base share of immobile firms increases from 0 to 1 . This is not as substantial as one would expect given that wind turbines cannot relocate. However, two facts might explain the result. First, governments care not only about tax revenue but also about employment and wind turbines do not generate employment. Second, governments might expect more wind turbines to come and thus do not increase the tax rate to the maximum.

To assess the sensitivity of our results, we run several robustness checks, which we report in Table A3 in Appendix A. In particular, the results are not sensitive to the time span as they prevail when we use all years between 1999 and 2011 and a trend variable to construct our excluded instruments (col. (1), Table A3). Furthermore, the definition of the tax base share of immobile firms does not drive our findings: In col. (2), we use the ratio of wind turbines' tax base to the observed tax base in 1998; and in col. (3) we use the logarithm of the number of turbines plus one. Lastly, we show that the sample does not drive our results. Col. (4) includes the wind strength in the set of matching variables and cols. (5) and (6) use the full sample. While we use in col. (5) the same instrument as in our baseline specification, we use in col. (6) the two separate instruments. Results are unchanged and the p-value of the Hansen tests 
Table 4: Estimation Results: Municipalities' Tax Rate Choices

\begin{tabular}{|c|c|c|c|c|c|c|}
\hline Dependent Variable & \multicolumn{6}{|c|}{ Local business tax multiplier (LBTM) } \\
\hline Method & \multicolumn{4}{|c|}{ OLS } & \multicolumn{2}{|c|}{ IV } \\
\hline Sample & \multicolumn{3}{|c|}{ 1999-2011 } & \multicolumn{3}{|c|}{$1999 \& 2011$} \\
\hline \multicolumn{7}{|l|}{ Exluded Instrument } \\
\hline Wind*REA* $\left(\frac{\text { Agric }}{\text { Agric }+ \text { Urban }}\right)$ & & & & & $\mathrm{x}$ & $\mathrm{x}$ \\
\hline \multicolumn{2}{|c|}{ Neighbor*Wind*REA* $\left(\frac{\text { Agric }}{\text { Agric }+ \text { Urban }}\right)$} & & & & & $\mathrm{x}$ \\
\hline & (1) & $(2)$ & $(3)$ & $(4)$ & (5) & $(6)$ \\
\hline \multirow[t]{2}{*}{ Real. TaxBaseShare IF } & $5.828^{* * *}$ & $5.464^{* * *}$ & $4.017^{* * *}$ & $7.034^{* * *}$ & $41.945^{* * *}$ & $37.157^{* * *}$ \\
\hline & $(1.139)$ & $(1.121)$ & $(1.125)$ & $(2.137)$ & $(10.148)$ & $(11.172)$ \\
\hline \multirow[t]{2}{*}{ Neighbor LBTM } & & & & & & 0.326 \\
\hline & & & & & & $(0.280)$ \\
\hline Control Variables & $\mathrm{x}$ & $\mathrm{x}$ & $\mathrm{x}$ & $\mathrm{x}$ & $\mathrm{x}$ & $\mathrm{x}$ \\
\hline Municipality FE & $\mathrm{x}$ & $\mathrm{x}$ & $\mathrm{x}$ & $\mathrm{x}$ & $\mathrm{x}$ & $\mathrm{x}$ \\
\hline State-Year FE & & & $\mathrm{x}$ & $\mathrm{x}$ & $\mathrm{x}$ & $\mathrm{x}$ \\
\hline$R^{2}$ & 0.212 & 0.222 & 0.289 & 0.471 & 0.421 & 0.465 \\
\hline Observations & 53,898 & 53,897 & 53,897 & 8,292 & 8,292 & 8,292 \\
\hline F-Statistic IV: TaxBase & & & & & 152 & 78 \\
\hline F-Statistic IV: Neighbor & & & & & & 53 \\
\hline \multicolumn{7}{|l|}{ First stage for tax base } \\
\hline Wind $^{*} \operatorname{REA}^{*}\left(\frac{\text { Agric }}{\text { Urban }+ \text { Agric }}\right)$ & & & & & $0.068^{* * *}$ & $0.063^{* * *}$ \\
\hline
\end{tabular}

Notes: This table shows estimated coefficients for the impact of the realized tax base share of immobile firms on municipalities' tax rate choice, estimated on a matched sample of municipalities with and without wind turbines. The dependent variable is the municipality specific local business tax multiplier. To derive the tax rate, the multiplier has to be multiplied with $5 \%$ before 2008 and with $3.5 \%$ after 2007. IF stands for immobile firms. In cols. (1) to (3) our sample spans all years from 1999 to 2011 and in cols. (4) to (6) only the years 1999 and 2011. Columns (1) to (4) report OLS estimates, and cols. (5) and (6) IV estimates. The excluded instrument for the tax base share of immobile firms is the interaction between wind strength, the ratio of agricultural to total (agricultural, urban and industrial) land, and a reform dummy (REA) that is one for years after 1999. The excluded instrument for the neighbor local business tax multiplier is the average interaction between wind strength, the ratio of agricultural to total (agricultural, urban and industrial) land, and a reform dummy (REA) within $20 \mathrm{~km}$ radius. All regressions include the log of population, the share of inhabitants under 6 and over 65 , the share of the political parties in the community council and wind strength 80 meters above ground and its interaction with the reform dummy as well as the natural logarithm of agricultural land and its interaction with the reform dummy. Standard errors, shown in parentheses, are robust to heteroscedasticity and clustered at the municipality level. ${ }^{* * *}, * *, *$ indicate significance at the $1 \%$, $5 \%, 10 \%$ levels.

Source: Authors' calculations based on Statistik Lokal, 1998 to 2011, data from the operator database, 1990 to 2011, and the German Weather Service. 
confirms the exogeneity of the instruments. Using the full sample we find clear evidence of tax competition between municipalities. The impact of neighbors' tax rate multiplier is 0.75 , significant at the $1 \%$ level.

To sum up, by exploiting the introduction of subsidies for wind turbines in 2000, we are able to show that municipalities increase the tax burden on firm profits if the average firm mobility in the jurisdiction decreases.

\section{Firm Level: Mobile Firm Entry and Anticipated Tax Rate Changes}

As we have seen in the last section, municipalities increase the tax burden on firm profits when the tax base share of immobile firms in the municipality increases. We now investigate the extent to which other (non-wind-turbine) firms anticipate future tax rate increases when making their location decisions. To gauge firms' expectations about future tax rates, we will use the potential tax base share of immobile firms. As firms' expectations matter, the potential tax base share is more appropriate than the realized tax base share, which we used in the previous section. This measure is also consistent with the model from Section 2, which showed in equation (3) that the increase in the tax rate after immobile firm entry depends on the potential tax base share of immobile firms.

\subsection{Descriptive Evidence}

The sample for the analysis of firms' location decisions includes all German municipalities. We use this sample as it allows us to exploit the full variation in the potential tax base share compared to the matched sample, in which all included municipalities have a relatively high likelihood that a wind turbine locates in that jurisdiction. ${ }^{29}$ In total, we observe 94,270 municipality-year observations between 1999 and 2006. Table 5 shows descriptive statistics for this sample. The average local business tax rate is around $16 \%$. On average, there are 4,350 inhabitants in a municipality and there are about eight new firms per year. The realized tax base share is around $2 \%$, the potential tax base share is $59 \%$. The correlation coefficient for the two tax base measures is 0.16 ,

\footnotetext{
${ }^{29}$ Although the sample size drops by about $75 \%$ when using the matched sample, point estimates for our preferred specification are very similar and available upon request.
} 
significant at the $1 \%$ level. We exclude the top $1 \%$ of municipalities with the highest average number of new firms to avoid that outliers drive the results.

Table 5: Descriptive Statistics Mobile Firms

\begin{tabular}{|c|c|c|c|c|c|}
\hline & Mean & $\mathrm{P} 25$ & $\mathrm{P} 50$ & P75 & $\mathrm{SD}$ \\
\hline Number of new firms (per year) & 8.27 & 0.00 & 2.00 & 7.00 & 18.16 \\
\hline Number of firm entries due to relocation (per year) & 1.15 & 0.00 & 0.00 & 1.00 & 3.11 \\
\hline Number of firm exits due to relocation (per year) & 1.10 & 0.00 & 0.00 & 1.00 & 3.01 \\
\hline Local Business Tax (LBT) & 0.16 & 0.15 & 0.17 & 0.17 & 0.02 \\
\hline Pot. TaxBaseShare IF & 0.59 & 0.26 & 0.66 & 0.93 & 0.35 \\
\hline Real. TaxBaseShare IF & 0.02 & 0.00 & 0.00 & 0.00 & 0.13 \\
\hline Spending in million euro & 8.34 & 0.91 & 2.30 & 7.39 & 17.77 \\
\hline Population in thousand & 4.35 & 0.57 & 1.43 & 4.21 & 8.16 \\
\hline Neighbor Spending in million euro & 298 & 124 & 195 & 323 & 382 \\
\hline Neighbor LBT $<20 \mathrm{~km}$ & 0.02 & 0.01 & 0.01 & 0.02 & 0.00 \\
\hline Neighbor Population in thous. $<20 \mathrm{~km}$ & 236 & 115 & 172 & 275 & 228 \\
\hline Neighbor Population in thous. $20 \mathrm{~km}<<40 \mathrm{~km}$ & 720 & 389 & 585 & 861 & 543 \\
\hline Area in hectare & 2,627 & 791 & 1,635 & 3,327 & 2,905 \\
\hline Agricultural land in hectare & 1,452 & 421 & 918 & 1,818 & 1,677 \\
\hline Number of students per 1000 capita & 7.41 & 0.00 & 0.00 & 9.10 & 15.00 \\
\hline Unemployment rate & 10.52 & 6.20 & 8.20 & 15.10 & 5.65 \\
\hline Doctors per 100.000 capita & 125 & 115 & 123 & 133 & 18 \\
\hline Observations & 94,270 & & & & \\
\hline
\end{tabular}

Source: Authors' calculations based on Statistik Lokal, 1999 to 2006, data from the operator database, 1990 to 2006, and the German Weather Service.

\subsection{Methodology and Results}

Following Brülhart et al. (2012) we estimate a Poisson model at the municipality level. Guimaraes et al. (2003) and Becker and Henderson (2000) show that the Poisson model is appropriate to estimate the determinants of the location decision based on the footloose start-up as well of latent start-up model..$^{30}$ Our estimation equation reads as follows:

\footnotetext{
${ }^{30}$ In footloose start-up models, a company decides where to locate among several jurisdictions. In latent start-up models, the company faces only the choice between starting business in a particular jurisdiction or not starting. The model presented in Section 2 is a latent start-up model.
} 


$$
N_{i, t}=\exp \left(\alpha_{1} \tau_{i, t}+\alpha_{2} \frac{T_{I, i, t}^{P}}{T_{0, i, t}}+\beta^{\prime} X_{i, t}+\delta_{i}+\rho_{t}+\epsilon_{i, t}\right)
$$

The dependent variable $N_{i, t}$ in our main specification is the number of new firms in municipality $i$ in year $t .{ }^{31} \tau_{i, t}$ is the tax rate, and $\frac{T_{I, i, t}^{P}}{T_{0, i, t}}$ the potential tax base share of immobile firms, which is a proxy for the future tax rate.

Our set of control variables, $X$, includes the municipality and regional characteristics described above (see Table 5). At the municipality level, we include public good provision (measured by municipality spending and the number of doctors), market potential (measured by municipality population), and municipality size (measured by area size). We also control for the amount of agricultural land interacted with year dummies to ensure that differences in agricultural land are not driving our estimates for the potential tax base share. ${ }^{32}$ At the regional level, we also control for public good provision (measured by the sum of spending of all municipalities within $20 \mathrm{~km}$ ) and market potential (measured by the population within $20 \mathrm{~km}$, and between 20 and $40 \mathrm{~km}$ ). Further, we include the inverse distance weighted average tax rate of the municipalities within $20 \mathrm{~km}$ distance to capture spillovers from neighboring municipalities. In addition we use information on the local labor market (the unemployment rate and the number of students), available at the county level. We also include a full set of year dummies $\left(\rho_{t}\right)$ which absorb business cycle effects, and a full set of municipality fixed effects $\left(\delta_{i}\right)$, which account for any unobserved time-constant heterogeneity. We report robust standard errors, clustered at the municipality level.

Table 6 presents the regression results. ${ }^{33}$ Column (1) displays the specification with the full set of control variables but without the potential tax base share. The results suggest a negative impact of the local business tax on firm entry. In col. (2) we include our future tax rate proxy. The precision of the estimate for the local business tax

\footnotetext{
${ }^{31}$ In principle, estimation at the municipality-industry level would be preferable as it allows to control for industry-wide shocks. However, given the large number of municipalities in Germany, this would result in a large share of zero firm entries, and thus overdispersion. We thus prefer the municipality level as it ensures a more reasonable distribution of firm entries. Furthermore, it allows us to interpret the estimated coefficients as average semi-elasticities. We will show in a sensitivity analysis that the results are qualitatively unchanged when estimating at the municipality-industry-level.

${ }^{32}$ We do not control for land price differences as they are endogenous (wind turbine subsidies capitalize into land prices Haan and Simmler, 2016). Time-invariant price differences are captured by the municipality specific effects.

${ }^{33}$ The number of observation is lower than in Table 5, as some municipalities with zero new firms in all years are dropped.
} 
Figure 7: Estimated Coefficients for Potential Tax Base Share Percentile Dummies

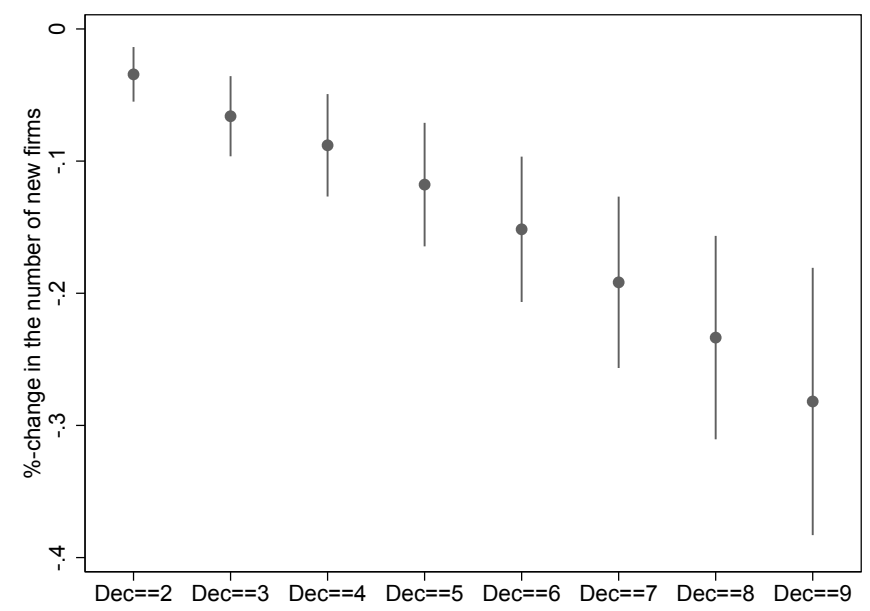

Notes: Graph shows estimated coefficients and 95\% confidence intervals for potential tax base share deciles dummies based on an otherwise identical specification as shown in col. (2) in Table 6. The maximum of the 9 th includes the 10 th percentile and thus only 8 point estimates are depicted.

increases and the coefficient for the tax base share is negative and significant. When including a full set of state-year fixed effects in col. (3), the results are unchanged. To assess the plausibility of the functional form, we estimate a more flexible specification (without including state-year fixed effects) using dummies for deciles of the potential tax base share of immobile firms. Figure 7 shows the point estimates for these dummies. The results are in line with the results of the less flexible specification.

In col. (4) we account for industry differences and estimate our specification on the municipality-2-digit-industry-year level. The results are qualitatively unchanged. Finally, we test whether our results are sensitive to the definition of the potential tax base share. In col. (3), we thus focus on the absolute number of wind turbines and assume that 28 turbines (the $99 \%$ percentile of wind turbines per municipality) are built in each municipality. The estimated coefficient, reported in col. (5), is also negative and significant at the $1 \%$ level.

In Table A4 in Appendix A, we report the estimated coefficients for the control variables in the Poisson model. All control variables that have a significant influence on the number of new firms have the expected signs. When including state-year fixed effects, most control variables become insignificant.

To compare the effects of the current tax rate and the future tax rate, we evaluate their impact on the number of new firms for an increase by one standard deviation. 
Table 6: Poisson Estimation of Firms' Location Choice

\begin{tabular}{|c|c|c|c|c|c|}
\hline \multirow[t]{2}{*}{ Dep. Var. } & \multicolumn{5}{|c|}{ Number of new firms } \\
\hline & (1) & $(2)$ & $(3)$ & (4) & (5) \\
\hline LBT & $\begin{array}{c}-1.838^{* *} \\
(0.918)\end{array}$ & $\begin{array}{c}-1.735^{* *} \\
(0.853)\end{array}$ & $\begin{array}{c}-1.806^{* *} \\
(0.820)\end{array}$ & $\begin{array}{c}-1.247^{* *} \\
(0.533)\end{array}$ & $\begin{array}{c}-1.730 * * \\
(0.853)\end{array}$ \\
\hline Pot. TaxBaseShare IF & & $\begin{array}{c}-0.246^{* * *} \\
(0.044)\end{array}$ & $\begin{array}{c}-0.125^{* * *} \\
(0.044)\end{array}$ & $\begin{array}{c}-0.123^{* * *} \\
(0.043)\end{array}$ & \\
\hline $\begin{array}{l}\text { Pot. TaxBaseShare IF } \\
\text { (28 turbines) }\end{array}$ & & & & & $\begin{array}{c}-0.298^{* * *} \\
(0.059)\end{array}$ \\
\hline Control Variables & $\mathrm{x}$ & $\mathrm{x}$ & $\mathrm{x}$ & $\mathrm{x}$ & $\mathrm{x}$ \\
\hline Agric. Land*Year-FE & $\mathrm{x}$ & $\mathrm{x}$ & $\mathrm{x}$ & $\mathrm{x}$ & $\mathrm{x}$ \\
\hline Municipality FE & $\mathrm{x}$ & $\mathrm{x}$ & $\mathrm{x}$ & $\mathrm{x}$ & $\mathrm{x}$ \\
\hline State-Year*FE & & & $\mathrm{x}$ & & \\
\hline Industry Dummies & & & & $\mathrm{x}$ & \\
\hline Log-likelihood & $-152,104$ & $-152,064$ & $-150,471$ & $-959,469$ & $-152,076$ \\
\hline Observations & 90,730 & 90,730 & 90,730 & $5,172,390$ & 90,730 \\
\hline
\end{tabular}

Notes: This table shows the estimated coefficients for the impact of the potential tax base share of immobile firms on the number of total firm entries per municipality and year based on Poisson estimations for the years 1999 to 2006. The potential tax base share of immobile firms is defined as the tax base of wind turbines that are built on 0.0042 of the agricultural land using latest available technology and the subsidized feed-in-tariff of the Renewable Energy Act, introduced in 2000, to the tax base in 1998 and the tax base of wind turbines. Heteroscedasticity-robust standard error in parentheses. ${ }^{* *},{ }^{* *},{ }^{*}$ indicate significance at the $1 \%, 5 \%, 10 \%$ levels.

Source: Authors' calculations based on Statistik Lokal, 1999 to 2006, data from the operator database, 1990 to 2006, and the German Weather Service. 
Based on the estimates in our preferred specification in col. (2), an increase in today's local business tax rate by one standard deviation (2 percentage points) reduces the number of new firms by $3.5 \%$, an increase in the potential tax base share by one standard deviation (35 percentage points) decreases the number of new firms by $9 \%$. We can use our estimate from the municipality level to translate the expected increase in the tax base share by 35 percentage points into a change in the local business tax. Based on the point estimate in col. (5) in Table 4, an increase in the tax base share by one standard deviation increases the local business tax multiplier by 15 points $\left(42^{*} 0.35\right)$. To derive the tax rate, this has to be multiplied by 0.05 . Thus, an increase in the tax base share by 35 percentage points translates into a tax rate increase by 0.75 percentage points. Using our estimate for the current tax rate shows that such a change today would reduce the number of firms by $1.3 \%$. This suggests that the impact of the future tax rate is substantially larger than that of the current tax rate. ${ }^{34}$

To assess the sensitivity of our results, we present the results of robustness tests in Table 7. First, we use a log-linear specification (col. 1). To avoid that zero entries are dropped from the sample, we transform the dependent variables using the hyperbolic sine transformation (IHS). The point estimate for the potential tax base share is again negative and significantly estimated and very similar to the Poisson estimate. Second, to rule out that our potential tax base share is merely a proxy for the realized tax base share of immobile firms, we estimate our estimation equation using the realized tax base share of immobile firms. Column (2) shows these results. The point estimate for the realized tax base share is much smaller and statistically not different from zero, confirming that the risk that wind turbines might enter drives firms away.

Third, we use the number of entries due to relocations as the dependent variable. For these firms we expect the current and future tax rate to have a larger impact as they are more likely to be profitable. In line with this presumption, col. (3) shows that the coefficient for the local business tax almost doubles and the coefficient for the tax base share of immobile firms almost triples.

\footnotetext{
${ }^{34}$ In principle, we can use our estimates to calculate the weights of the current and future tax rate. The impact of taxes on firms' location decision is given by $\beta\left(\alpha \tau_{\text {current }}+(1-\alpha) \tau_{\text {future }}\right)$ with $\beta$ as impact of taxes on firms' location decision and $\alpha$ as the weight of the current tax rate. If the current tax rate increases by 0.75 percentage points, the number of firms decreases by $1.3 \%(\beta \alpha)$. If the future tax rate changes by 0.75 percentage points, the number of firms decreases by $9 \%(\beta(1-\alpha))$. This would suggest a weight of the current tax rate of $12.6 \%$ and a weight of the future tax rate of $87.4 \%$. Since our proxy for the future tax rate is, however, likely to capture not only expectations but uncertainty as well, the weight for the current tax rate is likely to be underestimated.
} 
Table 7: Sensitivity Analysis: Firms' Location Choice

\begin{tabular}{lcccc}
\hline Model & $(1)$ & $(2)$ & $(3)$ & $(4)$ \\
Dep. Var. & IHS(Number) & $\begin{array}{c}\text { Number of } \\
\text { new firms }\end{array}$ & $\begin{array}{r}\text { Firm entry } \\
\text { due to relocations }\end{array}$ & $\begin{array}{c}\text { Firm exit } \\
\text { LBT }\end{array}$ \\
& -0.753 & $-1.835^{* *}$ & $-2.944^{*}$ & 1.830 \\
& $(0.460)$ & $(0.918)$ & $(1.552)$ & $(1.468)$ \\
Pot. TaxBaseShare IF & $-0.191^{* * *}$ & & $-0.598^{* * *}$ & $-0.345^{* * *}$ \\
& $(0.037)$ & & $(0.117)$ & $(0.123)$ \\
Real. TaxBaseShare IF & & -0.069 & 0.001 & $0.383^{*}$ \\
& & $(0.086)$ & $(0.185)$ & $(0.221)$ \\
\hline Control Variables & $\mathrm{x}$ & $\mathrm{x}$ & $\mathrm{x}$ & $\mathrm{x}$ \\
Agric. Land*Year-FE & $\mathrm{x}$ & $\mathrm{x}$ & $\mathrm{x}$ & $\mathrm{x}$ \\
Mun. FE & $\mathrm{x}$ & $\mathrm{x}$ & $\mathrm{x}$ & $\mathrm{x}$ \\
\hline Observations & 90,730 & 90,730 & 67,504 & 64,996 \\
\hline
\end{tabular}

Notes: Table shows estimated coefficients for the impact of the potential tax base share of immobile firms on different measures of firm entry/exit for the years 1999 to 2006. Col. (1) presents a log-linear specification. Col. (2) uses the realized instead of the potential tax base share as explanatory variable. Col. (3) considers firm entry due to relocations, and col. (4) firm exits. Heteroscedasticity-robust standard errors in parentheses. ${ }^{* *}, * *,{ }^{*}$ indicate significance at the $1 \%, 5 \%, 10 \%$ levels.

Source: Authors' calculations based on Statistik Lokal, 1999 to 2006, the operator database 1990 to 2006 and the German Weather Service. 
Lastly, to provide more evidence on the difference between the realized tax base share (which hinges on the entry of wind turbines) and the potential tax base share (which is independent of the actual entry of wind turbines) we use the number of firm exits due to relocations as dependent variable. Firm exits due to relocations should not respond to changes in the potential tax base as these firms always have the option to wait until wind turbines enter the municipality. Thus, for their decision, the realized tax base share of immobile firms should matter. Column (4) presents these results. The point estimate for the realized tax base share has the expected sign, it is positive and marginally significant. Thus, a higher share of immobile firms increases the number of firms relocating to other municipalities. The point estimate for the potential tax base share is negative but also statistically significant. One ex-post explanation for this finding could be that a tax increase is less likely when the potential tax base share is larger (for a given realized tax base share). The larger remaining potential gives the government a stronger incentive to keep rates down.

In total, these regressions confirm that firms avoid municipalities where they expect the tax rate to increase in the future, as proxied by the potential tax base share of wind turbines.

\section{Conclusion}

Our paper points to the commitment problem of governments: Low tax rates attract both firms with low and high relocation costs. Governments then face an incentive to increase the tax rate on immobile firms' profits once these firms have made their location decision.

We show in this paper that local governments indeed increase the tax rate if the average firm mobility decreases in their jurisdiction. Furthermore, firms anticipate government behavior and react thus to the current as well as the expected future tax rate when making their location decision. Finally, the risk of future tax increases deters firms from entering in a specific municipality.

Our results suggest that prior empirical estimates may have underestimated the role of taxation by focusing only on current but not future tax rates. In addition, they highlight the relevance of government credibility for effective tax policy for less mobile firms and how the presence of highly mobile firms mitigates the commitment problem, as these firms continue to pressure the government for a low tax rate in the future. 


\section{References}

Abadie, A., Imbens, G. W., 2008. On the failure of the bootstrap for matching estimators. Econometrica 76, 1537-1557.

Altshuler, R., Goodspeed, T. J., 2015. Follow the Leader? Evidence on European and US Tax Competition. Public Finance Review 43, 485-504.

Arif, S., Lee, C. M. C., 2014. Aggregate investment and investor sentiment. The Review of Financial Studies 27, 3241-3279.

Baldwin, R. E., Krugman, P., 2004. Agglomeration, integration and tax harmonisation. European Economic Review 48, 1-23.

Becker, J., Schneider, A., 2017. Taxation of firms with unknown mobility. Journal of Public Economic Theory, forthcoming.

Becker, R., Henderson, J. V., 2000. Effects of air quality regulations on polluting industries. Journal of Political Economy 108, 379-421.

Bond, E. W., Samuelson, L., 1986. Tax holidays as signals. American Economic Review $76,820-826$.

Borck, R., Pflüger, M., 2006. Agglomeration and tax competition. European Economic Review 50, 647-668.

Brülhart, M., Jametti, M., Schmidheiny, K., 2012. Do agglomeration economies reduce the sensitivity of firm location to tax differentials? Economic Journal 122, 1069-1093.

Carlsen, F., Langset, B., Rattsø, J., 2005. The relationship between firm mobility and tax level: Empirical evidence of fiscal competition between local governments. Journal of Urban Economics 58, 273-288.

Cummins, J. G., Hassett, K. A., Oliner, S. D., 2006. Investment behavior, observable expectations, and internal funds. American Economic Review 96, 796-810.

de Mooij, R. A., Ederveen, S., 2008. Corporate tax elasticities: a reader's guide to empirical findings. Oxford Review of Economic Policy 24, 680-697.

Devereux, M. P., Lockwood, B., Redoano, M., 2008. Do countries compete over corporate tax rates? Journal of Public Economics 92, 1210-1235. 
Doyle, C., Van Wijnbergen, S., 1994. Taxation of foreign multinationals: A sequential bargaining approach to tax holidays. International Tax and Public Finance 1, 211225.

Feld, L. P., Heckemeyer, J. H., 2011. FDI and taxation: A meta-study. Journal of Economic Surveys 25, 233-272.

Figueiredo, O., Guimarães, P., Woodward, D., 2002. Home-field advantage: location decisions of Portuguese entrepreneurs. Journal of Urban Economics 52, 341-361.

Fuest, C., Peichl, A., Siegloch, S., 2017. Do higher corporate taxes reduce wages? Micro evidence from Germany. American Economic Review, forthcoming.

Gennaioli, N., Ma, Y., Shleifer, A., 2015. Expectations and investment. NBER Working Paper 21260.

Gordon, R. H., 1992. Can capital income taxes survive in open economies? Journal of Finance 47, 1159-1180.

Greenwood, R., Hanson, S. G., 2015. Waves in ship prices and investment. Quarterly Journal of Economics 130, 55-109.

Guimaraes, P., Figueirdo, O., Woodward, D., 2003. A tractable approach to the firm location decision problem. Review of Economics and Statistics 85, 201-204.

Haan, P., Simmler, M., 2016. Wind electricity subsidies = windfall gains for land owners? Evidence from a feed-in tariff in Germany. DIW Discussion Paper 1568, Berlin.

Haupt, A., Krieger, T., 2013. The role of mobility in tax and subsidy competition. University of Freiburg Discussion Paper 2013-02.

Janeba, E., 2000. Tax competition when governments lack commitment: Excess capacity as a countervailing threat. American Economic Review 90, 1508-1519.

Jofre-Monseny, J., 2013. Is agglomeration taxable? Journal of Economic Geography 13, $177-201$.

Kehoe, P. J., 1989. Policy cooperation among benevolent governments may be undesirable. Review of Economic Studies 56, 289-296.

Koh, H.-J., Riedel, N., Böhm, T., 2013. Do governments tax agglomeration rents? Journal of Urban Economics 75, 92-106. 
Kydland, F. E., Prescott, E. C., 1980. Dynamic optimal taxation, rational expectations and optimal control. Journal of Economic Dynamics and Control 2, 79-91.

Marceau, N., Mongrain, S., Wilson, J. D., 2010. Why do most countries set high tax rates on capital?. Journal of International Economics 80, 249-259.

Ross, J. M., Carley, S., 2016. Do local governments site nuisance activities along borders? An empirical strategy applied to wind turbines. Indiana University working paper.

Slemrod, J., 2004. Are corporate tax rates, or countries, converging? Journal of Public Economics 88, 1169-1186.

Wang, Y.-Q., 1999. Commodity taxes under fiscal competition: Stackelberg equilibrium and optimality. The American Economic Review 89, 974-981.

Wildasin, D. E., 2003. Fiscal competition in space and time. Journal of Public Economics $87,2571-2588$.

Zwick, E., Mahon, J., 2017. Tax policy and heterogeneous investment behavior. American Economic Review 107, 217-48. 


\section{Appendix: Additional Tables}

Table A1: Predictive Power of Simulated Wind Turbines' Tax Base

\begin{tabular}{lcc}
\hline \multirow{2}{*}{ Dependent Variable } & \multicolumn{2}{c}{ Local business tax base } \\
\cline { 2 - 3 } & All Municipalities & $\begin{array}{c}\text { Without top and bottom } \\
1 \% \text { of } 1998 \text { tax base }\end{array}$ \\
\cline { 2 - 3 } & & $(2)$ \\
\hline L.Simulated TaxBase WindTurbines & $1.255^{* * *}$ & $0.899^{* * *}$ \\
& $(0.527)$ & $(0.347)$ \\
\hline$R^{2}$ & 0.007 & 0.027 \\
Observations & 156,324 & 138,614 \\
Municipality FE & $\mathrm{x}$ & $\mathrm{x}$ \\
\hline
\end{tabular}

Notes: Table shows estimated coefficients of the simulated tax base generated by wind turbines. The dependent variable is the municipality's overall tax base. Standard errors, shown in parentheses, are robust to heteroscedasticity and clustered at the municipality level. $* * *, * * *$ indicate significance at the $1 \%, 5 \%, 10 \%$ levels.

Source: Authors' calculations based on Statistik Lokal, 1998 to 2011, the operator database, 1990 to 2011, and the German Weather Service. 
Table A2: Descriptive Statistics: Treatment and Control Group Municipality Level 1998

\begin{tabular}{|c|c|c|c|c|c|c|}
\hline & \multicolumn{4}{|c|}{ Control Group } & \multicolumn{2}{|c|}{ Treatment Group } \\
\hline & \multicolumn{2}{|c|}{ Before Matching } & \multicolumn{2}{|c|}{ After Matching } & \multirow[b]{2}{*}{ Mean } & \multirow[b]{2}{*}{$\mathrm{SD}$} \\
\hline & Mean & $\mathrm{SD}$ & Mean & SD & & \\
\hline Local business tax multiplier & 322 & 32 & 328 & 36 & 331 & 41 \\
\hline Agricultural land price & 14,668 & 10,935 & 13,881 & 10,795 & 12,889 & 9,226 \\
\hline Log(Agricultural land price) & 9.32 & 0.78 & 9.22 & 0.84 & 9.20 & 0.77 \\
\hline Agricultural land & 1,328 & 1,415 & 2,630 & 2,017 & 3,523 & 3,384 \\
\hline Log(Agricultural land) & 6.72 & 1.04 & 7.60 & 0.82 & 7.76 & 0.97 \\
\hline Local business tax base in thous. euro & 457 & 4,857 & 855 & 6,015 & 1,225 & 8,105 \\
\hline $\log ($ Local business tax base in thous. euro) & 3.73 & 2.16 & 4.49 & 2.16 & 4.76 & 2.31 \\
\hline Population & 8,101 & 235,702 & 10,520 & 35,5052 & 14,862 & 48,569 \\
\hline Log(Population) & 7.61 & 1.29 & 8.24 & 1.28 & 8.44 & 1.48 \\
\hline
\end{tabular}

Notes: Before matching, there are 7,817 observations in the control group. After matching, the number of observations in treatment and control group is 2,073 each group.

Source: Authors' calculations based on Statistik Lokal, 1998, the German Weather Service and the operator database, 1990. 
Table A3: Sensitivity Analysis: Municipalities' Tax Rate Choice and the Tax Base Share of Immobile Firms

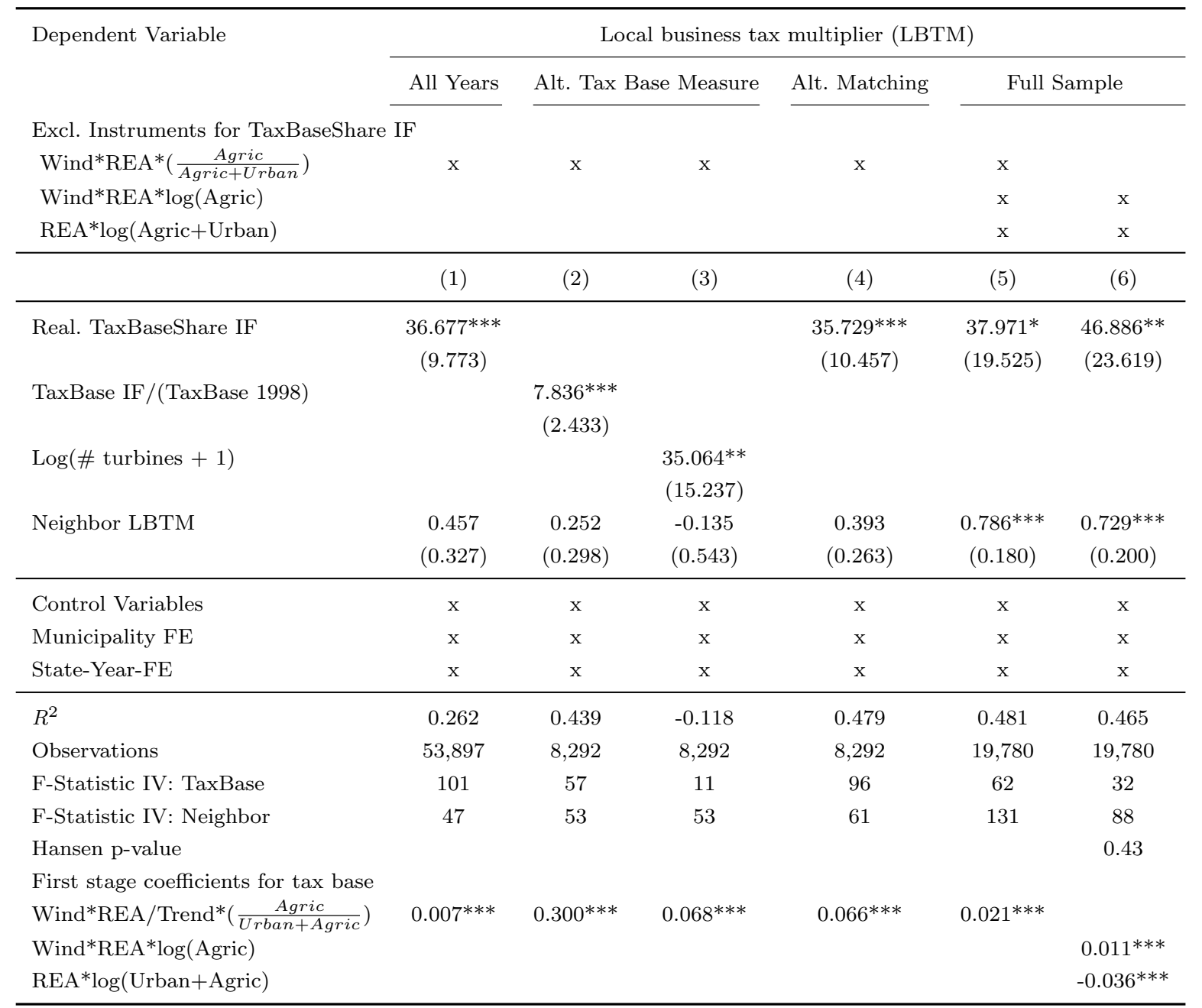

Notes: This table shows the results of sensitivity analysis for the impact of the share of immobile firms on municipalities' tax rate choices. The dependent variable is the municipality specific local business tax multiplier. To derive the tax rate the multiplier has to be multiplied with $5 \%$ before 2008 and with $3.5 \%$ after 2007. IF stands for immobile firms. In all columns we estimate instrumental variable fixed effect models using 1999 and 2011. The excluded instrument for the tax base share in cols. (1) to (5) is the interaction between the wind strength, the ratio of agricultural to urban and industrial land and, in col. (1), a trend variables or, in cols. (2) to (6), a reform dummy (REA) that is one for years after 1999. In col. (6) we use the interaction between wind strength, reform indicator and logarithm of agricultural land as well as the interaction between reform indicator and logarithm of urban, agricultural and industrial land. The excluded instrument for the neighbor tax rate multiplier is the average interaction between the wind strength, the ratio of agricultural to urban and industrial land and, in col. (1), a trend variables or, in cols. (2) to (6), a reform dummy within $20 \mathrm{~km}$ radius. Standard errors, shown in parentheses, are robust to heteroscedasticity and clustered at the municipality level. ${ }^{* * *},{ }^{* *}, *$ indicate significance at the $1 \%, 5 \%, 10 \%$ levels.

Source: Authors' calculations based on Statistik Lokal, 1998 to 2011, the operator database, 1990 to 2011, and the German Weather Service. 
Table A4: Control Variables Poisson Estimation of Firms' Location Choice

\begin{tabular}{|c|c|c|c|c|c|}
\hline \multirow{2}{*}{$\begin{array}{l}\text { Dep. Var. } \\
\text { Model }\end{array}$} & \multicolumn{5}{|c|}{$\begin{array}{l}\text { Number of new firms } \\
\text { per industry }\end{array}$} \\
\hline & $(1)$ & $(2)$ & (3) & $(4)$ & (5) \\
\hline Neighbor LBT & $\begin{array}{c}50.838^{* * *} \\
(18.910)\end{array}$ & $\begin{array}{c}50.980^{* * *} \\
(18.654)\end{array}$ & $\begin{array}{c}-5.914 \\
(22.902)\end{array}$ & $\begin{array}{c}37.174^{* *} \\
(15.560)\end{array}$ & $\begin{array}{c}50.758^{* * *} \\
(18.659)\end{array}$ \\
\hline Spending in million euro & $\begin{array}{c}0.001^{* * *} \\
(0.000)\end{array}$ & $\begin{array}{c}0.001^{* *} \\
(0.000)\end{array}$ & $\begin{array}{c}0.001 \\
(0.000)\end{array}$ & $\begin{array}{c}0.000 \\
(0.000)\end{array}$ & $\begin{array}{c}0.001^{* * *} \\
(0.000)\end{array}$ \\
\hline Neighbor spending & $\begin{array}{l}-0.000 \\
(0.000)\end{array}$ & $\begin{array}{l}-0.000 \\
(0.000)\end{array}$ & $\begin{array}{l}-0.000 \\
(0.000)\end{array}$ & $\begin{array}{c}0.000 \\
(0.000)\end{array}$ & $\begin{array}{l}-0.000 \\
(0.000)\end{array}$ \\
\hline Population in thousand & $\begin{array}{c}0.063^{* * *} \\
(0.019)\end{array}$ & $\begin{array}{c}0.063^{* * *} \\
(0.019)\end{array}$ & $\begin{array}{c}0.007 \\
(0.016)\end{array}$ & $\begin{array}{c}0.017^{* * *} \\
(0.006)\end{array}$ & $\begin{array}{c}0.064^{* * *} \\
(0.019)\end{array}$ \\
\hline Population in thousand, sqrd. & $\begin{array}{c}-0.001^{* * *} \\
(0.000)\end{array}$ & $\begin{array}{c}-0.001^{* * *} \\
(0.000)\end{array}$ & $\begin{array}{l}-0.000 \\
(0.000)\end{array}$ & $\begin{array}{c}-0.000^{* *} \\
(0.000)\end{array}$ & $\begin{array}{c}-0.001^{* * *} \\
(0.000)\end{array}$ \\
\hline Neighbor $<20 \mathrm{~km}$ Population in thousand & $\begin{array}{l}-0.000 \\
(0.001)\end{array}$ & $\begin{array}{l}-0.000 \\
(0.001)\end{array}$ & $\begin{array}{l}-0.000 \\
(0.001)\end{array}$ & $\begin{array}{l}-0.000 \\
(0.001)\end{array}$ & $\begin{array}{l}-0.000 \\
(0.001)\end{array}$ \\
\hline Neighbor $20 \mathrm{~km}<<40 \mathrm{~km}$ Population in thous. & $\begin{array}{c}0.001^{* * *} \\
(0.000)\end{array}$ & $\begin{array}{c}0.001^{* * *} \\
(0.000)\end{array}$ & $\begin{array}{l}-0.001^{*} \\
(0.000)\end{array}$ & $\begin{array}{c}0.001^{* * * *} \\
(0.000)\end{array}$ & $\begin{array}{c}0.001^{* * *} \\
(0.000)\end{array}$ \\
\hline Number of students & $\begin{array}{l}0.002^{* *} \\
(0.001)\end{array}$ & $\begin{array}{l}0.002^{*} \\
(0.001)\end{array}$ & $\begin{array}{l}0.002^{* *} \\
(0.001)\end{array}$ & $\begin{array}{c}0.001 \\
(0.001)\end{array}$ & $\begin{array}{c}0.002^{* *} \\
(0.001)\end{array}$ \\
\hline Unemployment rate & $\begin{array}{c}-0.015^{* * *} \\
(0.004)\end{array}$ & $\begin{array}{c}-0.014^{* * *} \\
(0.004)\end{array}$ & $\begin{array}{c}0.006 \\
(0.005)\end{array}$ & $\begin{array}{c}-0.010^{* * *} \\
(0.004)\end{array}$ & $\begin{array}{c}-0.015^{* * *} \\
(0.004)\end{array}$ \\
\hline Doctors per 1000 capita & $\begin{array}{c}0.001 \\
(0.001)\end{array}$ & $\begin{array}{c}0.001 \\
(0.001)\end{array}$ & $\begin{array}{c}0.000 \\
(0.001)\end{array}$ & $\begin{array}{l}0.001^{*} \\
(0.001)\end{array}$ & $\begin{array}{c}0.001 \\
(0.001)\end{array}$ \\
\hline Agric. Land*Year-FE & $\mathrm{x}$ & $\mathrm{x}$ & $\mathrm{x}$ & $\mathrm{x}$ & $\mathrm{x}$ \\
\hline Municipality FE & $\mathrm{x}$ & $\mathrm{x}$ & $\mathrm{x}$ & $\mathrm{x}$ & $\mathrm{x}$ \\
\hline $\begin{array}{l}\text { State-Year*FE } \\
\text { Industry Dummies }\end{array}$ & & & $\mathrm{x}$ & $\mathrm{x}$ & \\
\hline Log-likelihood & $-152,104$ & $-152,064$ & $-150,471$ & $-959,469$ & $-152,076$ \\
\hline Observations & 90,730 & 90,730 & 90,730 & $5,172,390$ & 90,730 \\
\hline
\end{tabular}

Notes: Table shows estimated coefficients for the control variables for the regression from Table 6 .

Heteroscedasticity-robust standard errors in parentheses. $* *, * *, *$ indicate significance at the $1 \%, 5 \%$, $10 \%$ levels.

Source: Authors' calculations based on Statistik Lokal, 1999 to 2006, the operator database 1990 to 2006 and the German Weather Service. 